\title{
Conditional Federal Spending: A Back Door To Enhanced Free Exercise Protection
}

\author{
Kimberly Sayers-Fay†
}

The Supreme Court's decision in Employment Division v. Smith eroded free exercise protection by announcing that neutral, generally applicable laws burdening free exercise do not have to meet the compelling interest test. Rather, rational basis scrutiny applies to all but "hybrid rights." Intent on restoring the stricter standard, Congress passed the Religious Freedom Restoration Act of 1993 (RFRA). After it failed to pass constitutional muster, Congress has continued to search for other ways to enhance free exercise protection. This Comment suggests a spendingbased strategy to do exactly that. It argues that by attaching carefully crafted conditions to a host of federal spending programs, Congress could accomplish some, but not all, of RFRA's objectives. Precisely because conditioning federal funds is not novel, this inherently inefficient approach may ultimately prove to be the most effective.

\section{INTRODUCTION}

"Congress shall make no law respecting an establishment of religion, or prohibiting the free exercise thereof ...." The language of the Free Exercise Clause seems simple. Its application, however, has proven otherwise. Nothing illustrates this better than the current religious freedom tugof-war between Congress and the United States Supreme Court.

At issue is the appropriate level of accommodation due citizens' religious beliefs. We have determined that laws that target particular

Copyright (C) 2000 California Law Review, Inc. California Law Review, Incorporated (CLR) is a California nonprofit corporation. CLR and the authors are solely responsible for the content of their publications.

Law Clerk to the Honorable William A. Fletcher, U.S. Court of Appeals for the Ninth Circuit; J.D., School of Law, University of California, Berkeley (Boalt Hall), 1999; B.S.F.S,, Georgetown University, 1992. I am tremendously grateful for the constructive feedback Professors Jesse Choper and Vikram Amar provided ine on this Comment, as well as for the able editing of Jason Beutler and the cntire CLR staff. My heartiest thanks, however, are reserved for iny lusband Andrew, who put up with my piles of paper and inuch, much more during the ups and downs of law school.

1. U.S. Const. amend. I. 
religious faiths or practices are deeply suspect. ${ }^{2}$ But what should happen when citizens' religious beliefs or practices collide with general laws-the laws we least expect to have any religious implications? Should the individual be required to conform his religious practices to the law, or should the law bend to accommodate the individual's religion? To what extent should we, or must we, tolerate religious exceptions to laws of general applicability? ${ }^{3}$

Since 1990, Congress and the Court have shot this issue back and forth. The first volley was Employment Division $v$. Smith ${ }^{4}$ in which a majority of the Court ${ }^{5}$ held that neutral laws of general applicability do not have to meet the compelling interest test. ${ }^{6}$ According to the Court, strict scrutiny should only be applied to general laws when those laws burden religious freedom plus some additional right. ${ }^{7}$

In 1993, Congress tried to trump the Court's controversial Smith decision by passing the Rehigious Freedom Restoration Act of 1993 (RFRA). ${ }^{8}$ The Act, which used the Fourteenth Amendment's enforcement power to restore the compelling interest test, proved only a short-lived success. In 1997, the Supreme Court struck down RFRA in the celebrated case, City of Boerne v. Flores. ${ }^{10}$ Boerne, which foreclosed the possibility of using Section 5 of the Fourteenth Amendment to enhance religious freedom, is the most recent salvo in the fight over free exercise. It may not be the last, however. Though Boerne closed the front door to enhanced free exercise protection, the back door ${ }^{11}$ remains open.

2. See, e.g., Church of the Lukumi Babalu Aye, Inc. v. City of Hialcah, 508 U.S. 520, 546 (1993) (stating that "[a] law burdening rehigious practice that is not neutral or not of general application must undergo the most rigorous scrutiny").

3. Or, as Professor Michael McConnell frames the issue, "Should [the Free Exercise Clause] be given a narrow interpretation, under which it would prohibit only deliberate discrimination against religion? Or should it be given a broad interpretation, under which it would provide maximum freedom for religious practice consistent with demands of public order?" Michael W. McConnell, Free Exercise Revisionism and the Smith Decision, 57 U. CHI. L. REv. 1109, 1111 (1990).

4. 494 U.S. 872 (1990).

5. Justice Blackmun dissented, joined by Justices Brennan and Marshall. Justice O'Connor concurred in the result but attacked the majority's reasoning.

6. See Smith, 494 U.S. at 881 .

7. See Smith, 494 U.S. at 881 . See infra note 267 and accompanying text for further discussion of this controversial "hybrid rights" exception.

8. 42 U.S.C. $\$ \S 2000 b b-b b-4$ (1995).

9. See U.S. CoNST. amend. XIV, $\S 5$ ("The Congress shall have power to enforce, by appropriate legislation, the provisions of this article.").

10. 521 U.S. 507 (1997).

11. Professor Albert Rosenthal introduced this apt metaphor. See Albert J. Rosenthal, Conditional Federal Spending and the Constitution, 39 STAN. L. REv. 1103, 1131 (1987) ("If the front door of the commerce power is open, it may not be worth worrying whether to keep the back door of the spending power tightly closed."). 
That back door is Article I, Section 8, Clause 1 of the U.S. Constitution-the Spending Clause. ${ }^{12}$ This clause empowers Congress to spend for the "general welfare." 13 In the past, Congress has spent in ways that effectively buy states' cooperation. In the 1980s, for example, Congress effectively purchased a national drinking age of twenty-one by threatening to withhold federal highway funds from states that refused to comply. ${ }^{14}$ The question is, can Congress buy enhanced free exercise protection through similar spending maneuvers? Can Congress achieve indirectly through spending the goal that the Boerne Court has held it cannot directly legislate?

The answer is a qualified yes. By attaching strings to a host of federal spending programs, Congress can accomplish some, but not all, of RFRA's objectives. Faced with the prospect of losing their federal funds for noncompliance, states are likely to adopt or enact the protections Congress desires. Strategic spending thus offers an alternative to the legislative approach invalidated in Boerne and to the variant of it Congress is currently trying to resuscitate through the Religious Liberty Protection Act of 2000. ${ }^{15}$ This Comment explores this spending alternative in depth. Specifically, it seeks to illustrate how Congress could proinote free exercise without exceeding constitutional limits by attaching conditions on federal spending programs.

This spending approach is admittedly a suboptimal strategy to enhance religious freedom. ${ }^{16}$ Part I of this Comment relates the case-based

12. The Spending Clause provides: "The Congress shall have Power To lay and collect Taxes, Duties, Imposts, and Excises, to pay the Debts and provide for the common Defence and general Welfare of the United States." U.S. CONST. art. I, § 8, cl. 1.

13. See id.

14. For a thorough account of how Congress achieved a uniform national drinking age by conditioning federal highway funds, see James V. Corbelli, Note, Tower of Power: South Dakota v. Dole and the Strength of the Spending Power, 49 U. PITT. L. REv. 1097 (1988).

15. H.R. 1691, 106th Cong. (1999). This Act, described more fully infra Part I.D, passed the House on July 15, 1999 by a vote of 306-118. See 145 CoNG. REc. H5608 (daily ed. July 15, 1999). H.R. 1691 was reported to the Senate and referred to the Senate Judiciary Committee. See 145 CoNG. REC. S15068 (daily ed. Nov. 19, 1999). It was then introduced into the Senate as S. 2081, the Religious Liberty Protection Act of 2000, on February 22, 2000. The next day it was placed on the Senate Legislative Calendar. See Bill Summary \& Status for 106th Congress, S. 2081 (visited Mar. 15, 2000) <http://thomas.loc.gov>.

16. This strategy proposed herein is suboptimal for two reasons. First, it is inefficient, and with inefficiency comes inequity. This strategy aims to enhance free excereise protection where doing so is possible, not where doing so is desireable. For soine, this coinpromise is unacceptable. See, e.g., Michael P. Farris, Facing Facts: Only a Constitutional Amendment Can Guarantee Religious Freedom For All, 21 CARDOzo L. REv. 689, 691 (1999) (arguing that any compromise solution should be rejected). What troubles me inore than the end, lowever, is the ineans. It was not so long ago that I was a higln school senior, sitting dejectedly in the gallery of my state legislature as my representatives debated, ever so briefly, whether to raise the drinking age froin nineteen to twenty-one to maintain federal highway funds. The strategy was not pretty then, and it is no more so now. But it is an effective strategy, and if it is worthwhile to employ to purchase a national drinking age, it is worthwhile to employ in the service of the First Amendment. 
colloquy between Congress and the Court that forecloses other options. Part II then outlines the constitutional constraints that limit a spendingbased strategy to protect religious freedom. That Part focuses primarily on South Dakota v. Dole, ${ }^{17}$ which defines the parameters of what Congress can do when attaching striugs to federal funds. Part III then identifies and evaluates specific federal grant programs that provide Congress the opportunity to impose conditions protective of free exercise but still consistent with the constraints set out in Dole.

If Dole were indelibly etched in the constitutional landscape, no further analysis would be warranted. But Dole appears increasingly anomalous when compared to the Court's more recent decisions bearing on the federal-state balance. As previously noted, City of Boerne v. Flores reduced Congress's powers under the Fourteenth Amendment. Two years before Boerne, the Court curbed Congress's power under the Commerce Clause. ${ }^{18}$ More recently, the Court has evidenced its growing preoccupation with state sovereignty in Kimel v. Florida Board of Regents, ${ }^{19}$ Alden $v$. Maine, ${ }^{20}$ and Printz $v$. United States. ${ }^{21}$

Simply put, in the decade snice Dole the tide may have turned. Five new justices have jonied the Supreme Court. ${ }^{22}$ In view of the dramatic personnel changes and the Court's growing appreciation for states' rights, whether Dole could garner a majority today is questionable. Calls for the Court to "revisit" the decision have becoine increasingly frequent. ${ }^{23}$ Because of Dole's apparent vulnerability, this Comment concludes with an evaluation of how the conditions suggested in Part III would fare under leading Spending Clause reform proposals. Part IV focuses on the most

17. 483 U.S. 203 (1987).

18. See United States v. Lopez, 514 U.S. 549, 561 (1995) (holding that Congress exceeded its authority under the Commerce Clause with the Gun-Free School Zones Act of 1990 because the tie to interstate commerce was too tenuous).

19. 120 S.Ct. 631, 650 (1999) (holding that the Age Discrimination in Employment Act did not validly abrogate states' sovereign immunity from suit by private individuals).

20. 119 S.Ct. 2240,2246 (1999) (holding that "the powers delegated to Congress under Article I of the United States Constitution do not include the power to subject nonconsenting States to private suits for damages in state courts").

21. 521 U.S. 898, 933 (1997) (holding that Congress cannot require state officials to administer or enforce federal laws).

22. New to the Court since Dole are Justices Thomas, Kennedy, Souter, Breyer, and Ginsburg. For a persuasive argnment that Justice Thomas's concurring opinion in Lopez suggests a willingness to overrule Dole, see Lynn A. Baker, Conditional Federal Spending After Lopez, 95 Colum. L. Rev. 1911,1914 n.12 (1995).

23. See, e.g., id. (noting that because Dole offered Congress an easy end run around any restrictions the Constitution might impose on its ability to regulate the states, "a reexamination of Dole should be next on the Lopez majority's agenda"); Robert A. Hammeke, State Autonomy Implications for Congressional Conditional Spending, 24 OKLA. CITY U. L. Rev. 349 (1999); Ryan C. Squire, Note, Effectuating Principles of Federalism: Reevaluating the Federal Spending Power as the Great Tenth Amendment Loophole, 25 PEPP. L. REv. 869 (1998). 
likely successor doctrine: Justice O'Connor's interpretation of the spending power as advanced in her Dole dissent.

I

\section{Background: Congress and the Court Clash over Free Exercise}

\section{A. Round One: Smith Scuttles the Compelling Interest Test}

It was better to be a Catholic during prohibition than a Native American Church inember during the inodern war on drugs. ${ }^{24}$ That is at least one interpretation of Employment Division v. Smith, ${ }^{25}$ the case that touched off the unprecedented religious freedoin tug-of-war between Congress and the Court.

Smith involved a free exercise challenge by two Native American Church (NAC) members. Smith and Black were counselors for the Douglas County Council on Alcohol and Drug Abuse Prevention and Treatment (ADAPT) ${ }^{26}$ They qualified for that position in part because of their own past drug and alcohol dependencies. ${ }^{27}$ As a condition of einployment, ADAPT required its counselors to abstain from the use of alcohol and illegal drugs. ${ }^{28}$ Upon learning that these two counselors had ingested a small amount of peyote at a NAC ceremony, ADAPT fired them, citing intentional violation of employer rules. ${ }^{29}$

Both Smith and Black eventually sought unemployment compensation. ${ }^{30}$ The Einployment Division considered their applications in a series of hearings and appeals, ultimately denying their applications. ${ }^{31}$ The Division considered the men ineligible for benefits because they had been discharged for work-related "misconduct." ${ }^{\text {"32 }}$ The discharged counselors

24. In his Smith dissent, Justice Blackmun noted that Catholics' sacramental use of wine was exeinpted during prohibitiou. See Einployment Div. v. Smith, 494 U.S. 872, 913 n.6 (1990) (Blackmun, J., dissenting) (citing the National Prohibition Act of 1919, ch. 85, title II, § 3, 41 Stat. 305, 308 (1919) (repealed 1935)).

25. 494 U.S. 872 (1990). The Smith case has a long and convoluted history, having reached the Oregon Supreme Court three times and the U.S. Supreme Court twice. In this Comment, unless stated otherwise, all references to Smith are references to Employment Division v. Smith, 494 U.S. 872 (1990) ("Smith II"), which came before the U.S. Supreme Court in 1990. For a thorough explication of the issues presented in Employment Division v. Smith, 485 U.S. 660 (1988) ("Smith $\Gamma$ '), or in the Oregon Supreme Court, Smith v. Employment Division, 763 P.2d 146 (Or. 1988), see David Leventhal, Note, The Free Exercise Clause Gets a Costly Workout in Employinent Division, Department of Hunan Resources of Oregon v. Smith, 18 PEPP. L. REv. 163 (1990).

26. See Einployınent Div. v. Smith, 485 U.S. 660, 662 (1988) (Smith I).

27. See id.

28. See id.

29. See id.

30. See id at 663 .

31. See id.

32. See id. at 663-64. The Court cited the then-applicable definition of misconduct:

Or. Rev. Stat. $\$ 657.17(2)$ (a) (1987) provides that '[a]n mdividual shall be disqualified from the receipt of benefits ... if ... the individual ... [h] as been discliarged for misconduct connected with work.' 
challenged the Division's decision, contending that Oregon could not condition the availability of unemployment benefits on their willingness to forego conduct required by their religion, even if that conduct was illegal. ${ }^{33}$ The Oregon Supreme Court agreed. In Smith v. Employment Division, ${ }^{34}$ the Oregon court held that the "denial of unemployment benefits significantly burdened Smith's free exercise rights" in violation of the Free Exercise Clause. ${ }^{35}$

The U.S. Supreme Court disagreed. In Smith I, the Supreme Court reversed, holding that free exercise protection does not extend to conduct that a state validly proscribes. ${ }^{36}$ The Court remanded the case to the Oregon Supreme Court, however, because it detected some ambiguity about whether Oregon's drug law actually encompassed sacramental peyote use. ${ }^{37}$

On remand, the Oregon court held that the sacramental peyote use did fall under the ambit of Oregon's drug law. ${ }^{38}$ It also held, however, that the law was unconstitutional as applied:

We conclude that the Oregon statute against possession of controlled substances, which includes peyote, makes no exception for the sacramental use of peyote, but that outright prohibition of good faith religious use of peyote by adult members of the Native American Church would violate the First Amendment directly and as interpreted by Congress. We therefore reaffirm our holding that the First Amendment entitles petitioners to unemployment compensation. ${ }^{39}$

The U.S. Supreme Court again granted certiorari. Writing for the Court, Justice Scalia stated that the First Amendment's Free Exercise Clause permits a state to criminalize sacramental peyote use, and thus also permits the state to deny unemployment benefits to persons discharged for such use..$^{40}$ Justice Scalia maintained that "[w]e have never held that an individual's religious beliefs excuse him from compliance with an

Oregon Admin. Rule 471-30-038(3) (1987) provides: 'Under the provisions of ORS $657.176(2)$ (a) and (b), misconduct is a willful violation of the standard of behavior which an employer has the right to expect of an employee. An act that amounts to a willful disregard of an employer's interest, or recurring negligence is misconduct. Isolated instances of poor judgment, good faith errors, unavoidable accidents, absences due to illness or other physical or mental disabilities, or inere inefficiency resulting from lack of job skills or expcrience are not misconduct for the purposes of denying benefits under ORS 657.176.'

Id. at 664 n. 6 (omissions and alterations in original).

33. See Employment Div. v. Smith, 494 U.S. 872, 876 (1990).

34. 721 P.2d 445 (Or. 1986).

35. Id. at 450 .

36. See Smith, 485 U.S. at 671.

37. See id. at 672.

38. See Smith v. Employment Div., 763 P.2d 146, 148 (Or. 1988).

39. Id.

40. See Employment Div. v. Smith, 494 U.S. 872, 879-82 (1990). 
otherwise valid law prohibiting conduct that the State is free to regulate."41 To do so, he said, would be to court anarchy" by "mak[mg] the professed doctrines of religious belief superior to the law of the land, and in effect ... permit[ting] every citizen to become a law unto himself."43

Smith was certainly significant for its particular result. Ingesting peyote was part and parcel of Smith and Black's faith. ${ }^{44}$ In many ways it was more than a sacrament, since peyote itself constitutes an object of worship for the Native American Church. ${ }^{45}$ Peyote use is somewhat analogous to Catholics' use of wine, except that while many Catholics drink wine outside of church, Native Americans consider nonreligious peyote use sacrilegious. ${ }^{46}$

Even more arresting than the Court's particular result, however, was the mode of analysis it employed to evaluate the men's free exercise claim. Departing from settled First Amendment jurisprudence, ${ }^{47}$ the Court eliminated strict scrutiny in most free exercise contexts. ${ }^{48}$ This action was all the more surprising because to many, Smith looked like a modern version of the landmark case Sherbert $v$. Verner, which first established strict scrutiny's applicability in the context of free exercise. ${ }^{49}$

Like Smith, Sherbert also concerned a state's denial of unemployment benefits to someone whose religious practices purportedly rendered them meligible. Under South Carolina law, a person was ineligible for benefits "[i]f . . he has failed, without good cause . . . to accept available suitable work when offered him by the employment office or the employer." ${ }^{50} \mathrm{Be}$ cause Sherbert refused to work on Saturdays, the Sabbath of her Sabbatarian faith, South Carolina's Employment Security Commission

41. Id. at 878-79.

42. See id. at 888.

43. Id. at 879 (quoting Reynolds v. United States, 98 U.S. 145, 166-67 (1879)).

44. See Employment Div. v. Smith, 485 U.S. 660,663 (1988) (stating that "[i]t is undisputed that respondents are members of [the NAC], that their religious beliefs are sincere, and that those beliefs motivated the 'misconduct' that led to their discliarge"); Smith, 763 P.2d at 148 (noting that "[t]o prohibit the use of peyote "results in a virtual inhibition of the practice of defendants' religion" (quoting People v. Woody, 394 P.2d 813, 818 (Cal. 1964))).

45. See Smith, 763 P.2d at 148.

46. See id; Woody, 394 P.2d at 818.

47. So contends Justice Blackmun, with whon Justices Brennan and Marsliall join, in his Smith disseut. See Smith II, 494 U.S. at 908 (Blackmun, J., dissenting). Justice O'Connor concurred in Smith II but disagreed with the majority's rationale, whicl she maintained "dramatically departs from wellsettled First Amendment jurisprudence, appears unnecessary to resolve the question presented, and is iucompatible with our Natiou's fuudamental commitment to individual religious liberty." Id. at 891 (O'Connor, J., concurring).

48. See id. at 881-82. Three years after Smith $I I$, the Court affirmed that strict scrutiny still applies to laws that are not neutral or of general application and that burden free exercise. See Church of the Lukumi Babalu Aye, Inc. v. City of Hialeah, 508 U.S. 520, 546 (1993).

49. 374 U.S. 398, 404 (1963).

50. Id. at 401 (citation omitted). 
determined that she did not meet this "good cause" requirement $t^{51}$ and demied her unemployment compensation benefits. ${ }^{52}$ The Supreme Court rejected South Carolina's analysis. The Court held that the South Carolina law, which failed to recognize a religious objection to Saturday work, burdened Sherbert's free exercise of her religion. ${ }^{53}$ Since no compelling state interest justified this burden, the Court rejected the South Carolina ruling on unemployment benefits. ${ }^{54}$

Sherbert clearly einbraced the compelling interest test for free exercise challenges. By contrast, the Smith majority found the test inapplicable. Justice Scalia thought it wholly inappropriate to apply to neutral laws the same test that is applied elsewhere to laws that single out racial minorities or particular speakers: "What [the coinpelling interest test] produces in those other fields-equality of treatinent and an unrestricted flow of contending speech-are constitutional norms; what it would produce here-a private right to ignore generally applicable laws-is a constitutional anomaly." $\mathrm{se}$ He thus concluded that "the sounder approach" is to hold the compelling interest test inapplicable to such challenges. ${ }^{56}$

\section{B. Round Two: Congress Responds With the Religious Freedom Restoration Act}

It did not take long for Congress to recognize and reject Justice Scalia's "sounder approach." As one Senate committee report succinctly noted:

The effect of the Smith decision has been to hold laws of general applicability that operate to burden religious practices to the lowest level of scrutiny ... the 'rational relationship test' .... By lowering the level of constitutional protection for religious practices, [Smith] has created a climate in which the free exercise of religion is jeopardized..$^{57}$

Congress quickly recognized that more than sacramental peyote use was at stake. Indeed, the Native Americans' practice was only the tip of the iceberg: "Since Smith was decided, governments throughout the U.S. have run roughshod over religious conviction. Churches have been zoned even out of commercial areas. Jews have been subjected to autopsies in violation of their families' faith. $* * *$ In time, every religion in America will suffer." ${ }^{\text {s }}$

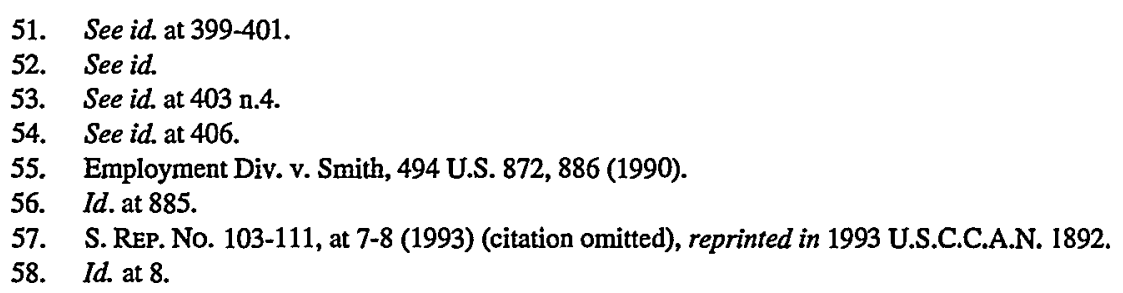


Others shared this fear. As Professor Michael McConnell points out, a bevy of "facially neutral" laws burdens free exercise:

Employment discrimination laws conflict with the Roman Catholic male priesthood; laws against serving alcoholic beverages to minors conflict with the celebration of communion; regulations requiring hard hats in construction areas can effectively exclude Amish and Sikhs from the workplace ... zoning laws interfere with religious ministries; laws requiring jury service conflict with the tenets of Jehovah's Witnesses; laws giving historic preservation commissions authority over changes im old buildings, if applied to churches, can result in official second-guessing of ecclesiastical decisions; and laws establishing the schedule of compulsory public schools conflict with the prayer requirements of Muslim students. ${ }^{59}$

The sheer number of laws affecting religion suggests that if religion is not better accommodated, religious freedom may become seriously eroded.

Perceiving this threat, an unusually broad coalition of religious groups and civil liberties organizations lobbied Congress to blnnt Smith's mupact. ${ }^{60}$ Congress responded with the Religious Freedom Restoration Act of 1993

59. Michael W. McConnell, Accommodation of Religion, 60 GEO. WASH. L. REv. 685, 694 (1992).

60. One of these groups was the Coalition for Free Exercise of Religion. According to Douglas Laycock and Oliver Thomas, this coalition also included: Agudath Israel of America; American Association of Christian Schools; American Civil Liberties Union; American Conference on Religious Movements; American Humanist Association; American Jewish Committee; American Jewish Congress; American Muslim Council; Americans for Democratic Action; Americans for Religious Liberty; Americans United for Separation of Clurch and State; Anti-Defamation League; Association of Christian Schools International; Association on American Indian Affairs; Baptist Joimt Committee on Public Affairs; B'nai B'rith; Central Conference of American Rabbis; Christian Churcli (Disciples of Christ); Christian College Coalition; Christian Legal Society; Christian Life Commission of the Southern Baptist Convention; Christian Science Committee on Publication; Church of the Brethren; Church of Jesus Christ of Latter-day Saints; Churcli of Scientology International; Coalitions for America; Concerned Women for America; Council of Jewish Federations; Council on Religious Freedom; Episcopal Clurch; Evangelical Lutheran Church in America; Federation of Reconstructionist Congregations and Havurot; First Liberty Institute; Friends Committee on National Legislation; General Conference of Seventh-day Adventists; Guru Gobind Singlı Foundation; Hadassah, The Women's Zionist Organization of America, Inc.; Home School Legal Defense Association; House of Bishops of the Episcopal Churcli; International Institute for Religious Freedom; Japanese American Citizens League; Jesuit Social Ministries, National Office; Justice Fellowship; Mennonite Central Committee U.S.; NA'AMAT USA; National Association of Evangelicals; National Council of Churches; National Council of Jewish Women; National Drug Strategy Network; National Federation of Temple Sisterhoods; National Islamic Prison Foundation; National Jewisly Commission on Law and Public Affairs; National Jewislı Community Relations Advisory Council; National Sikh Center; Native American Church of North America; North American Council for Muslim Women; People for the American Way Action Fund; Presbyterian Clurclı (USA), Social Justice and Peacemaking Unit; Rabbinical Council of America; Traditional Values Coalition; Union of American Hebrew Congregations; Union of Orthodox Jewislı Congregations of America; Unitarian Universalist Association of Congregations; United Clurcll of Christ, Office for Church in Society; United Methodist Church, Board of Churclı and Society; Umited Synagogue of Conservative Judaism. See Douglas Laycock \& Oliver S. Thomas, Interpreting the Religious Freedom Restoration Act, 73 TEx. L. REv. 209, 210 n.9 (1994). 
(RFRA), ${ }^{61}$ co-sponsored by the unlikely duo of liberal Senator Edward Kennedy and conservative Senator Orrin Hatch. ${ }^{62}$ The Act sailed through the Senate by a vote of 97 to $3,{ }^{63}$ while the House's approval was unanimous. ${ }^{64}$ President Clinton signed the bill into law on November 16, 1993. ${ }^{65}$

RFRA explicitly sought to overrule Smith and reinstate the compelling interest test that previously applied in the free exercise context. ${ }^{66}$ Indeed, the Act's stated purpose was "to restore the compelling interest test as set forth in Sherbert v. Verner and Wisconsin v. Yoder and to guarantee its application in all cases where free exercise of religion is substantially burdened." ${ }^{167}$ Section 3 of the Act reinstated a familiar formulation of the compelling interest test: "Government may substantially burden a person's exercise of religion only if it demonstrates that application of the burden to the person (1) is in furtherance of a compelling governmental interest; and (2) is the least restrictive means of furthering that compelling governmental interest." ${ }^{68}$ By adopting the compelling interest test, RFRA avoided endorsing particular outcomes. House Committee members made this clear, using Smith as a case in point: "[T]he Committee neither approves nor disapproves of the result in any particular court decision involving free exercise of religion.... [T] his bill would not mandate that all states permit the ceremonial use of peyote, but it would subject any such prohibition to the aforesaid [compelling interest] test." ${ }^{\text {" }}$ RFRA raised the bar, but it did not dictate particular results.

In enacting RFRA, Congress relied on its Fourteenth Amendment enforcement power. ${ }^{70}$ Congress reasoned that congressional power under Section 5 of the Fourteenth Amendment included congressional power to enforce the Free Exercise Clause. ${ }^{71}$ Because RFRA was "clearly designed to implement the Free Exercise Clause," Congress concluded that promulgating the Act "falls squarely within" this power. ${ }^{72}$

\section{Round Three: Boerne Deals RFRA a Death Blow}

RFRA did not last long. When the city of Boerne, Texas challenged the constitutionality of the Act, the Court struck it down. Congress, it said,

\footnotetext{
61. See 42 U.S.C. $\$ \S 2000 \mathrm{bb}-\mathrm{bb}-4$ (1995).

62. See 140 CoNG. REC. S5014 (daily ed. May 3, 1994) (statement of Sen. Hatch).

63. See 139 CoNG. REC. $S 14,470$ (daily ed. Oct. 27, 1993).

64. See 139 Cong. ReC. H2363 (daily ed. May 11, 1993).

65. See 139 Cong. REc. D1315 (daily ed. Nov. 16, 1993).

66. See, e.g., S. REP. No. 103-111, at 11 (1993), reprinted in 1993 U.S.C.C.A.N. 1892.

67. 42 U.S.C. $\$ 2000 \mathrm{bb}(\mathrm{b})(1)$ (1995) (internal citations omitted).

68. 42 U.S.C. $\$ 2000 \mathrm{bb}-1$ (1995).

69. H.R. REP. No. 103-88, at 7 (1993).

70. See S. REP. No. 103-111, at 14 (1993), reprinted in 1993 U.S.C.C.A.N. 1892; H.R. REP. No. 103-88, at 9 (1993).

71. See S. Rep. No. 103-111, at 14 .

72. S. Rep. No. 103-111, at 14 (1993).
} 
had exceeded its power. ${ }^{73}$ The Court was not persuaded that by enacting RFRA, Congress was merely exercising its remedial power to enforce the Free Exercise Clause of the First Amendment. ${ }^{74}$ Rather, the Court perceived that Congress was attempting to define the substance of that right. ${ }^{75}$

Writing for the majority, Justice Kennedy opmed, "[1]egislation which alters the meaning of the Free Exercise Clause cannot be said to be enforcing the Clause."76 He continued, "[Congress] has been given the power 'to enforce,' not the power to determine what constitutes a constitutional violation." position as the law of the land. ${ }^{78}$

\section{Round Four?: The Proposed "Religious Liberty Protection Act of 2000"}

Congress has not gone quietly into the night. Indeed, on July 15 , 1999, the House passed the Religious Liberty Protection Act of 1999 (RLPA). ${ }^{79}$ This second run at the Smith decision is now under consideration in the Senate,,$^{80}$ and its prognosis is unclear. ${ }^{81}$

RLPA is an attempt to accomplish what RFRA sought to do through Section 5 of the Fourteenth Amendment through the more conventional vehicles of the spending and commerce powers. Section 2 of the bill provides that:

Except [when the government demonstrates a compelling interest], a government shall not substantially burden a person's religious exercise-

(1) in a program or activity, operated by a government, that receives Federal financial assistance; or

73. See City of Boerne v. Flores, 521 U.S. 507, 529-36 (1997).

74. See id. at 532-34.

75. See id. at 532. The Boerne Court had earlier rejected the notion that Congress's power may extend beyond the remedial: "Any suggestion that Congress has a substantive, non-remedial power under the Fourteenth Amendment is not supported by our case law." Id. at 527.

76. Id. at 519.

77. Id.

78. See id. at 534. Citing ambiguity in Boerne itself, some maintain that RFRA is constitutional as apphied to the federal government, even though it is unconstitutional as applied to the states. See, e.g. , In re Hodge, 220 B.R. 386, 395 (D. Idaho 1998) (holding that "RFRA survived Flores, albeit only in the federal realm"); Steckler v. United States, 1998 WL 28235, at *2 (E.D. La. 1998) ("[R]equirements of RFRA remain in effect with regard to federal laws and regulations."). Other commentators have argued strenuously against this position. See, e.g., Marci A. Hamilton, The Religious Freedom Restoration Act is Unconstitutional, Period, 1 U. PA. J. Const. L. 1 (1998); Edward J.W. Blatnik, Note, No RFRAF Allowed: The Status of the Religious Freedom Restoration Act's Federal Application in the Wake of City of Boerne v. Flores, 98 Colum. L. REv. 1410 (1998).

79. H.R. 1691, 106th Congress (1999).

80. See S. 2081. The naine has since been changed to the Religious Liberty Protection Act of 2000. See supra note 15 .

81. See Adelle M. Banks, Key Groups Withdraw Support for Religious Liberty Protections, OregoniaN, Sept. 24, 1999, at A11, available in 1999 WL 28262968. 
(2) in any case ... which ... affects ... commerce with foreign nations, among the several States, or with the Indian tribes, even if the burden results from a rule of general applicability. ${ }^{82}$

Though RLPA relies in part on the spending power, it does so in a way that is quite different from the manner I shall propose. Rather than obtaining states' cooperation by conditioning federal funds, RLPA seeks to make states liable for burdening free exercise by authorizing private rights of action. ${ }^{83}$ In other words, government entities administering federal programs will do so with a greater sensitivity to citizens' free exercise rights not because of the threat of funds cancellation, but rather because of the threat of lawsuits. Of course, a citizen's right to sue a state is in some circumstances limited to prospective mjunctive relief, and this act does nothmg to change that. ${ }^{84}$

The advantage of RLPA over the strategy I suggest is clear: Congress can reach far more action more efficiently. But as Part III.A elucidates, that may also be its constitutional Achilles heel. Attaching one condition to all federal funding requires Congress to pin its strategy to only a very generalized government interest. ${ }^{85}$ This leaves it vulnerable to a Court that appears to be growing less imclined to accept attenuated rationales.

\section{E. Smith's Free Exercise Implications}

Congress and a broad array of interest groups inounted a vigorous assault on Smith. Notwithstanding that assault, the decision survives. In the parlance of lawyers, the case is "good law." To nany, however, no description could be further from the truth.

Consider the case of Neng Yang. Yang was a young Hmong man who died unexpectedly in his sleep.$^{86}$ Noting the unexplained nature of the death, Rhode Island's medical examiner conducted an autopsy. ${ }^{87}$ It later turned out that the examiner had exceeded his authority in doing so. ${ }^{88} \mathrm{It}$ also turned out that autopsies are deeply offensive to Hmong religious beliefs. ${ }^{89}$ As a result of the autopsy, Yang's parents believed that their

82. H.R. 1691, 106th Cong. \& 2 (1999).

83. See S. 2148, 105th Cong. \& 4(a) (1998) (stating that "[a] person may assert a violation of this Act as a claim or defense in a judicial proceeding and obtain appropriate relief against a government"). Section 2(c) explicitly provides that the bill does not authorize the withholding of federal funds as a remedy for violations.

84. See Legislation to Protect Religious Liberty: Hearings Before the Senate Comm. on the Judiciary, 106th Cong. (1999) (statement of Douglas Laycock, Professor, Univ. of Tex. Law School), available in 1999 WL 20011243, at *25 [hereinafter Layeock Testimony].

85. Douglas Laycock has stated that the "federal interest [protected by RLPA] is simply that the intended beneficiaries of federal progranis not be excluded because of their religious practice." Laycock Testimony, supra note 84 , at $* 2$.

86. See Yang v. Sturner, 728 F. Supp. 845, 846 (D.R.I. 1990).

87. See id.

88. See id. at $846-47$.

89. See Yang v. Sturner, 750 F. Supp. 558, 558 (D.R.I. 1990). 
son's spirit would never be free and would eventually return to take another person in his family. ${ }^{90}$

Neng Yang's family sued Dr. Sturner, the Rhode Island inedical examiner who conducted the autopsy. Ruling on cross-motions for suinmary judgment, the district court found that Dr. Sturner was liable to the Yangs for his violation of their First Amendment rights. ${ }^{91}$ Finding the medical examiner's justification for the autopsy "far short of being compelling," the court set a date to determine the amount of damages. ${ }^{92}$

That date never came. Nime months after the court ruled in their favor, the Yangs' case was dismissed. ${ }^{93}$ Judge Pettine wrote:

It is with deep regret that I have determined that the Employment Division case [Smith II] mandates that I recall my prior opmion. ... [T]he majority's decision in Employment Division effectuates a wholesale overturning of settled law concerning the Religion Clauses of our Constitution....

....

$\ldots[T]$ he opimion stands for the proposition that generally applicable, religion-neutral laws that have the effect of burdening a particular religious practice need not be justified by a compelling government imterest.

While I feel constrained to apply the majority's opinion to the instant case, I cannot do this without expressing iny profound regret. ${ }^{94}$

Under Smith, Rhode Island can infringe the Yang family's religious convictions without a compelling purpose. Indeed, the state does not even have to have a good reason for doing so; it just cannot have one particular type of bad one-hostility toward religion. This is no doubt small comfort to the Yangs, and probably to other Americans as well. Smith relegates the First Amendment's Free Exercise Clause to "a largely redundant equal protection clause for religion. ${ }^{95}$ Thus for the Yangs and other believers, ${ }^{96}$ Smith is not "good law."

90. See id.

91. See Yang, 728 F. Supp. at 852.

92. Id. at 857 .

93. See Yang, 750 F. Supp. at 560.

94. Id. at 558-59 (citations omitted).

95. McConnell, supra note 3, at 1153.

96. The Yangs are not alone in their predicament. For example, in Montgomery v. County of Clinton, 743 F. Supp. 1253, 1259 (W.D. Mich. 1990), the court, applying the Smith standard, dismissed a religious challenge to an unauthorized autopsy brought by a Jewish mother, holding that " $[$ there is no contention that the laws under which the autopsy was authorized are other than generally apphicable and religion-neutral." In Snyder v. Holy Cross Hosp., 352 A.2d 334 (Md. Ct. Spec. App. 1976), a Jewish Orthodox father lost a similar challenge. Because that case occurred in 1976, however, the court apphed the coinpelling interest test and upheld the constitutiouality of the unauthorized autopsy on the plaintiff's 18-year-old son only after finding that the state's interest in resolving the cause of death outweighed the father's religious objections. See id. at 341; see also Vermont v. Chambers, 477 A.2d 
II

\section{Constitutional Constraints on Conditioning Federal Funds}

Congress may not be able to overturn Smith, but it can blunt its impact. By attaching carefully crafted conditions to an array of federal funds, Congress can ensure that states treat at least some collisions between general laws and religious practices more generously than Smith requires. Congress's license to attach strings, however, is not completely unfettered. The constraints on Congress's power fall into two categories: limitations on objectives that spending prograins can pursue and limitations on the form and substance of conditions themselves.

\section{A. Limitations on Spending Program Objectives}

The spending power provides, "The Congress shall have Power ... [to] provide for the ... general Welfare of the Umited States ... "97 Early on, the proper interpretation of this clause was controversial. Jaines Madison arrived at his interpretation of the power conferred by taking a holistic view of Article I. Because the power to spend for the general welfare precedes the delineation of Congress's enumerated powers, ${ }^{98}$ Madison argued that the Spending Clause empowered Congress only to spend in furtherance of the powers specifically enumerated later in the section. ${ }^{99}$ In other words, Congress could spend in order to raise an army, coin money, regulate commerce, and so on, but not for purposes other than these. By contrast, Alexander Hamilton adamantly maintained that the Spending Clause conferred a power separate and distinct from those that followed it. ${ }^{100}$

The Court put this controversy to rest in 1936. In United States v. Butler, the Court sided with Hamilton. ${ }^{101}$ The enumerated powers do not limit the purposes for which Congress can spend. ${ }^{102}$ Limits on spending, ${ }^{103}$

110 (Vt. 1984) (rejecting a claim that an unauthorized autopsy on plaintiff's daughter violated his free exercise rights).

97. U.S. Consr. art. I, \& 8, cl. 1 .

98. These powers include, inter alia, the power to regulate commerce, coin money, declare war, raise and support an army, and to "make all Laws which shall be uecessary and proper for carrying into Execution the foregoing Powers." U.S. CoNST. art. I, § 8, cl. 18.

99. See United States v. Butler, 297 U.S. 1, 65 (1936). One problem with Madison's logic is that it creates redundancy within the Constitution. If his interpretation of the Spending Clause is correct, it would seem that the power it confers would be subsumed by that conferred later in the section by the Necessary and Proper Clause.

100. See id. at 65-66.

101. See id. at 66 .

102. See id. ("[T]he power of Cougress to authorize expenditure[s] . . . is not limited by the direct grants of legislative power fouud in the Constitution.").

103. In Butler the Court actually referred to the power to tax, but the context and subsequent discussion reveal that the court viewed the two powers as essentially interchangeable. See id. 
the Court held, are "set in the clause which confers it, and not in those of § 8."104

There is only one limit on the spending power in the "clause which confers it." That limit is that spending must be for "the general Welfare."105 Although the Court in Butler did not define general welfare, the Court undertook this task one year later in Helvering $v$. Davis. ${ }^{106}$ The Helvering Court adopted an extreinely deferential standard of review: "[W]e ... require a showing that by no reasonable possibility can the challenged legislation fall within the wide range of discretion permitted to the Congress."107 Thus, Congress was left broad discretion to determine what type of spending promotes the general welfare. The fox was now guarding the hen house.

This reality has not escaped the current Court. In South Dakota $v$. Dole, ${ }^{108}$ Chief Justice Rehnquist commented on how watered-down the general welfare "limitation" has become: "The level of deference to the congressional decision is such that the Court has inore recently questioned whether 'general welfare' is a judicially enforceable restriction at all."109 To say that the Court has "questioned" whether the restriction is judicially enforceable is an understatement. In Buckley v. Valeo, ${ }^{110}$ the Court opined that it was "erroneous" for appellants to regard the General Welfare Clause as a limitation upon congressional power at all. ${ }^{111}$ According to Buckley, the general welfare is what Congress says it is. ${ }^{112}$

Unsurprisingly, Congress has exploited its carte blanche. The power to spend for the general welfare has been harnessed to appropriate funds for local police forces, fire departments, neighborhood schools, sewer

104. Id. Despite this pronouucement, however, the Court subsequently found that the Agricultural Adjustment Act challenged in Butler was unconstitutional because it violated the Tenth Amendment. Gerald Gunther raises an interesting question with regard to this result. "If the power to spend for the 'general Welfare' is not limited by other grants of power in Art. I, § 8, why was it unconstitutional to spend for the purpose of reducing agricultural production, even though that production was not (in 1936) directly reachable under the other powers?" Gerald GunTHer, Constitutional Law 191 (12th ed. 1991). Gunther suggests that the inajority may have adopted the Madisonian position after all. See id.; see also David E. Engdahl, The Spending Power, 44 Duke L.J. 1 (1994) (arguing that the Court has consistently endorsed Hamilton's view but actually decided cases more in line with Madison's position).

105. U.S. CoNST. art. $1, \S 8, \mathrm{cl} .1$.

106. 301 U.S. 619 (1937).

107. Id. at 641 (citations omitted).

108. 483 U.S. 203 (1987).

109. Id. at $207 \mathrm{n} .2$ (1987) (citation omitted).

110. 424 U.S. 1 (1976).

111. Id. at 90 ("Appellants' 'general welfare' contention erroneously treats the General Welfare Clause as a limitation upon congressional power. It is rather a grant of power, the scope of which is quite expansive, particularly in view of the enlargement of power by the Necessary and Proper Clause.") (citations omitted).

112. See id. ('It is for Congress to decide which expenditures will pronote the general welfare."). 
systems, urban renewal projects and local water projects. ${ }^{113}$ Because the general welfare is what Congress says it is, the requirement poses no obstacle to spending that furthers a free exercise agenda. If Congress says that furthering free exercise advances the general welfare, the Court's current precedent leaves it little room to second-guess that judgment.

\section{B. Constraints on Conditions: Dole's Four-Part Test}

Although Congress's ability to appropriate funds for any purpose is virtually unchecked, its ability to attach conditions to those funds is not similarly unfettered. Constraints on Congress's power to "fix the terms upon which its ... allotments to the states shall be disbursed"114 derive primcipally from South Dakota v. Dole. ${ }^{115}$ In Dole, South Dakota challenged the constitutionality of 23 U.S.C. $\S 158$, which conditioned receipt of a percentage of federal highway funds upon adoption of a legal drinking age of twenty-one. ${ }^{116}$ South Dakota challenged the law on fairly narrow grounds. The state maintained that the federal government's attempt to induce change in its drinking age contravened the Twenty-First Amendınent. ${ }^{117}$ The Supreme Court, however, discarded that claim and instead decided the case by evaluating the constitutionality of the condition itself. ${ }^{118}$

Under Dole, spending conditions must satisfy four criteria to comport with the Constitution. ${ }^{119}$ First, the overall spending program to which conditions are attached must be in pursuit of the general welfare. ${ }^{120}$ As explained above, this criterion does not present a significant obstacle since Congress enjoys wide latitude in defining the general welfare. ${ }^{121}$ Including this formality in the Dole test is likely a deferential nod to history, and nothing more.

113. See Donald J. Mizerk, Note, The Coercion Test and Conditional Federal Grants to the States, 40 VAND. L. REV. 1159, 1165 (1987).

114. Oklahoma v. United States Civil Serv. Comm'n, 330 U.S. 127, 143 (1947).

115. 483 U.S. 203 (1987).

116. Id. at 205.

117. See id. Section 2 of the Twenty-First Amendment reads: "The transportation or importation into any State, Territory, or possession of the United States for delivery or use therein of intoxicating liquors, in violation of the laws thereof, is hereby prohibited." U.S. CoNST. amend. XXI, $\S 2$. Construing this provision, the Court had earlier held that the "Twenty-first Amendment grants the States virtually complete control over whether to permit importation or sale of liquor and how to structure the liquor distribution system." Dole, 483 U.S. at 205 (quoting California Retail Liquor Dealers Ass'n. v. Midcal Aluminum, Inc., 445 U.S. 97, 110 (1980)). South Dakota argued that the setting of the drinking age was within the "core powers" reserved to the states under Section 2 of the Amendment. See Dole, 483 U.S. at 205.

118. See Dole, 483 U.S. at 206.

119. See id. at 207-08.

120. See id. at 207.

121. See supra notes $105-13$ and accompanying text. 
The second Dole criterion poses a similarly low hurdle. Conditions on federal funds must be explicit. ${ }^{122}$ The Court explained the rationale for this requirement in Pennhurst State School and Hospital v. Halderman. ${ }^{123}$ The Pennhurst Court characterized the federal-state grant relationship as a contract, the legitimacy of which rests on states' voluntary and knowing acceptance of the terms. ${ }^{124}$ "Accordingly," the Court held, "if Congress intends to impose a condition on the grant of federal moneys, it must do so unambiguously." ${ }^{25}$ This requirement restricts conditions' form but not their content. Because of its cosmetic rather than substantive nature, this criterion is also unlikely to impair strategic spending aimed at increasing free exercise protection. Indeed, this second criterion is unlikely to foil any conditions, whatever their objective. ${ }^{126}$

The third criterion the Dole Court itself characterized as an "unexceptional proposition." 127 Congress may not use conditions to induce states to engage in activities that are themselves unconstitutional. ${ }^{128}$ That is, there can be no "independent constitutional bar." ${ }^{129}$ For example, Congress cannot condition funds on the infliction of cruel and unusual punishment or on invidiously discriminatory state action. ${ }^{130}$ Hypothetical violations of the "independent constitutional bar" prohibition are easy to imagine. Actual violations, however, are difficult to find.

Finally, and most importantly, the Court addressed the relatedness requirement. Chief Justice Rehnquist began by downplaying the criterion: "[O]ur cases have suggested (without significant elaboration) that conditions on federal grants might be illegitimate if they are unrelated to

\footnotetext{
122. See Dole, 483 U.S. at 207.

123. 451 U.S. 1 (1981).

124. See id. at 17.

125. Id.
}

126. The Fourth Circuit did, however, recently strike down a condition on federal funds because it fouud the condition ambiguous. In Virginia v. Riley, 106 F.3d 559, 561 (4th Cir. 1997), the Fourth Circuit held that the language of the Individuals with Disabilities Education Act (IDEA) was ambiguous and Virginia was not obliged to provide free appropriate public education to handicapped students expelled or suspended for criminal or other serious misconduct wholly unrelated to their disabilities as a condition of the state's receipt of federal funds under IDEA. The "condition" at issue, however, was expressed in only the vaguest of terms. IDEA required states to "assure[] all children with disabilities the right to a free appropriate public education." 20 U.S.C. § 1412(1) (Supp. 1996). Four months after Riley, Congress amended IDEA. It now provides that in order to receive federal educational funds, states must demonstrate that they have policies in effect that ensure that "[a] free appropriate publie education is available to all children with disabilities residing in the State between the ages of 3 and 21, iuclusive, including children with disabilities who have been suspended or expelled from school." IDEA Amendments for 1997, Pub. L. No. 105-17, § 612, 111 Stat. 37, 60 (1997).

127. Dole, 483 U.S. at 210.

128. See id.

129. Id.

130. See id. at 210-11. 
the federal interest in particular national projects or programs."131 Following this limp statement, Chief Justice Rehnquist, writing for the majority, concluded that the drinking age condition was directly related to one of the inain purposes of highway funds-safe interstate travel. ${ }^{132}$

This goal of the interstate highway system had been frustrated by varying drinking ages annong the States. A Presidential commission appointed to study alcohol-related accidents and fatalities on the Nation's highways concluded that the lack of uniformity in the States' drinking ages created 'an incentive to drink and drive' because 'young persons commut[e] to border States where the drinking age is lower.' By enacting $\S 158$, Congress conditioned the receipt of federal funds in a way reasonably calculated to address this particular impediment to a purpose for which the funds are expended. ${ }^{133}$

As Justice O'Connor points out, the "direct" relationship the Chief Justice perceived actually indulged several inferences: "The Court reasons that Congress wishes that the roads it builds may be used safely, that drunken drivers threaten highway safety, and that young people are more likely to drive while under the influence of alcohol under existing law than would be the case if there were a uniform national drinking age of 21."134 While these are not outlandish inferences, they are inferences just the same, and their very presence suggests that the relationship under consideration is not, in fact, direct.

In her Dole dissent, Justice O'Connor dismissed Rehnquist's relatedness analysis as "cursory." 135 It was, and there may be a reason for that. The Chief Justice may not have demanded a strong correlation between the condition and the purpose of the spending program because he may not truly believe such a nexus is necessary. Indeed, Pennhurst State School and Hospital $v$. Halderman ${ }^{136}$ suggests Chief Justice Rehnquist takes a fundainentally different view of the constitutionality of conditions than does Justice O'Connor.

In Pennhurst, Chief Justice Rehnquist indicated that the legitimacy of conditions derives from contract principles. "[L]egislation enacted pursuant to the spending power is much in the nature of a contract: in return for federal funds, the States agree to comply with federally imposed conditions." ${ }^{137}$ States, in other words, can agree to anything as long as they

131. Id. at 207 (quoting Massachusetts v. United States, 435 U.S. 444, 461 (1978) (plurality opinion)).

132. See id. at 209.

133. Id. (alteration in original) (internal citation omitted).

134. Id. at 213 (O'Connor, J., dissenting). See infra Part IV.A for further discussion of Justice O'Connor's Dole dissent.

135. Id.

136. 451 U.S. 1 (1981).

137. Id. at 17. 
know what they are getting themselves into. The presence or absence of a regulatory character is immaterial: 'The legitimacy of Congress' power to legislate under the spending power... rests on whether the State voluntarily and knowingly accepts the terms of the "contract."'138

Pennhurst is surely not a full explication of Chief Justice Rehnquist's views on the origin of the power to condition funds. The case may explain, however, why the Chief Justice appears to exalt form over substance in respect to this fourth criterion, and why he indulged so many inferences in finding a direct relationship im Dole. It may be that the Chief Justice is simply willing to tolerate quite attenuated relationships between programs and conditions attached to them. It may also be the case that he and his colleagues are willing to do so because they perceive the legitimacy of conditions as deriving from contract principles rather than from the spending power per se. Either imterpretation dictates a relaxed relatedness analysis favorable to free exercise advocates.

Depending on one's perceptions, Dole is either a crack in the constitutional foundation ${ }^{139}$ or an opportunity begging to be exploited. Its construction of the spending power is extremely generous. It is true that, in a footnote, the Court reserved the issue of "whether conditions less directly related to the particular purpose of the expenditure might be outside the bounds of the spending power." ${ }^{\text {"140 }}$ The footnote tells Congress it does not have carte blanche. The entire opinion, however, siguals that it does have substantial latitude. Free exercise advocates enjoy a lot of room to maneuver.

\section{The Twin Prohibitions on Coercion and Compulsion}

In the decade since Dole, the decision's four requirements have foiled few conditions. While the four formal requirenents seem destined to slumber, an additional criterion has increasingly attracted courts' attention. That criterion is the so-called "coercion test."

In the final paragraphs of his Dole opinion, Chief Justice Rehnquist observed: "Our decisions have recognized that in some circumstances the financial inducement offered by Congress might be so coercive as to pass the point at which 'pressure turns into compulsion."'141 Having introduced this potential bombshell, the Chief Justice then dismissed it summarily: "[A]ll South Dakota would lose if she adheres to her chosen course... is $5 \%$ of the funds otherwise obtainable under specified

138. Id.

139. See, e.g., Squire, supra note 23, at 870 (opining that "[t]he expansion of the Spending Clause power over the course of the twentieth century has rendered illusory the protections of state sovereignty and ensuing protections against tyranny").

140. Dole, 483 U.S. at 209 n.3.

141. Id. at 211 (quoting Steward Machine Co. v. Davis, 301 U.S. 548, 590 (1937)). 
highway grant programs."142 "We cannot conclude, however, that a conditional grant of federal money of this sort is unconstitutional simply by reason of its success in achieving the congressional objective."143

Fifty years before Dole, Justice Cardozo cautioned the Court against importing just such a coercion criterion. In Steward Machine Co. v. Davis, ${ }^{144}$ he wrote that "to hold that motive or temptation is equivalent to coercion is to plunge the law in endless difficulties." 145 History has by and large borne him out: the coercion test has not fared well. Unsurprisingly given the absence of key definitions, courts have not agreed on the level at which an inducement becomes coercive. Doctrine declares that there is a line, but case law shows that its placement varies according to where the case is filed.

A coinparison of two recent Spending Clause cases illustrates this point well. In 1997, the Fourth Circuit held that the Department of Education's threat to withhold all of Virginia's $\$ 60$ million special education grant because the state failed to provide private educational services to a small fraction of handicapped students "beg[an] to resemble impermissible coercion." 146 In contrast, a Kansas district court recently held that conditioning all of Kansas' federal funding for child support enforcement and all of its federal funding for aid to needy families with children on the state's impleinentation of a child support enforcement program did not constitute coercion. ${ }^{147}$ Courts cannot even agree on whether making one hundred percent of a state's grant contmgent is coercive; thus, it is no wonder they have immense troubles with lesser proportions.

Expressing a common criticism, a Kansas court recently called the coercion test "ill-conceived and probably unworkable." ${ }^{48}$ The Ninth Circuit suggested that the coercion criterion is a contradiction in terms, asking whether "a sovereign state which is always free to increase its tax revenues [can] ever be coerced by the withholding of federal funds ..." or whether "the state [is] merely presented with hard political choices." 149 The D.C. Circuit perceived the situation similarly, noting that " $[t]$ he courts are not suited to evaluating whether the states are faced ... with an offer they cannot refuse or inerely a hard choice." 150

A pair of recent Supreine Court cases suggests that a more streamlined query may eventually replace the coercion criterion. In New York $v$.

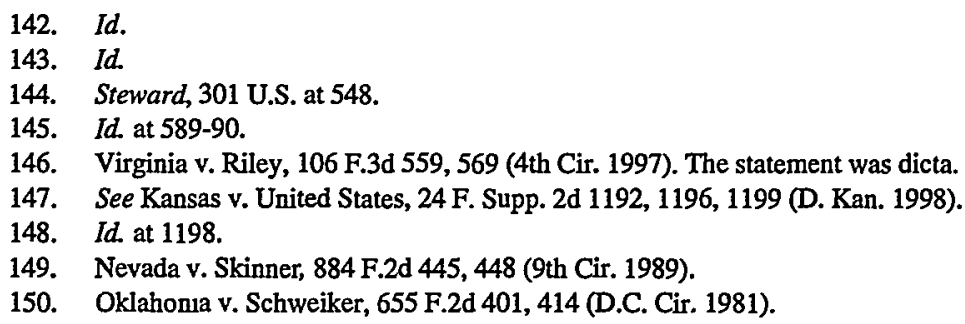


United States $^{151}$ and Printz $v$. United States, ${ }^{152}$ the Court seemed to recast the coercion criterion. In these cases, the Court queried only whether the program was literally an offer states could not refuse. By substituting a compulsion inquiry for the coercion one, the Court indicated that however powerful conditions may be, they are constitutional so long as states retain the formal option to opt out.

New York $v$. United States showed this new compulsion criterion in action. In New York, the Court struck down the "take title" provision of the Low-Level Radioactive Waste Policy Amendments Act. ${ }^{153}$ That provision, unlike its two companions that survived constitutional scrutiny, presented states with a Hobbesian choice: Either they had to "take title" to radioactive waste generated within their borders or they had to regulate the storage and disposal of such waste according to Congress's direction. ${ }^{154}$ The Supreme Court held that this "choice" offended the Tenth Amendment. ${ }^{155}$ "[O]ne thing is clear: the Federal Government may not compel the States to enact or administer a federal regulatory program." 156

Five years later the Court reiterated this theme. In Printz, the Court struck down a provision of the Brady Act that obliged local law enforcement officers to conduct background checks on prospective gun buyers. ${ }^{157}$ The Court was again offended that Congress was trying to compel states to administer a federal regulatory program: "We held in New York that Congress cannot compel the States to enact or enforce a federal regulatory program. Today we hold that Congress cannot circumvent that prohibition by conscripting the State's officers directly." 158

The lesson for free exercise advocates is clear. As enthusiasm for the "coercion test" has waned, regard for the "compulsion test" has risen. In part this has clarified the legal landscape. The Supreme Court has clearly staked out a boundary, declaring that Congress cannot make states offers they literally cannot refuse. At the same time, it has said nothing about Congress's practice of making offers, such as the 5\% contingency in Dole, which anount to offers states cannot realistically or politically refuse. Thus, the Court has tacitly condoned the use of large carrots (and large sticks) to induce states' cooperation. By steering clear of edicts and conditioning only modest amounts of spending program funds, efforts to secure state compliance with congressional free exercise priorities would likely enjoy substantial latitude.

\footnotetext{
151. 505 U.S. 144 (1992).

152. 521 U.S. 898 (1997).

153. See New York, 505 U.S. at 188.

154. See id. at 175.

155. See id. at 177.

156. Id. at 188.

157. See Printz, 521 U.S. at 933.

158. Id. at 935 .
} 


\section{Establishment Clause Concerns}

In his short concurrence in Boerne, Justice Stevens opined that RFRA violated the Establishment Clause. ${ }^{159}$ His argument was simple: By giving religious entities a "legal weapon that no atheist or agnostic can obtain,"160 RFRA ensconced a "governmental preference for religion, as opposed to irreligion" that the First Amendment forbids. ${ }^{161}$

None of the other justices shared Justice Stevens' Establishment Clause concern. Despite this lack of Supreme Court support, the struggle to resurrect RFRA, coupled with the proliferation of state RFRAs, ${ }^{162}$ has intensified the debate over whether statutes permitting religious exemptions from generally applicable laws are laws "respecting an establishment of religion." 63 This topic has deservedly been the focus of numerous academic articles, both endorsing ${ }^{164}$ and criticizing ${ }^{165}$ the theory. Although the complexity of this controversy defies capture here, a brief explanation of why the First Amendment tolerates religious exemptions, whether omnibus or ad hoc, is in order.

Justice Stevens took issue with RFRA's scheme because it did not treat religion and irreligion equally. ${ }^{166}$ Professors Christopher Eisgruber and Lawrence Sager cite the same problein: "RFRA's compelling state interest test privileges religious believers by giving thein an ill-defined and potentially sweeping right to claim exemption from generally applicable

159. See City of Boerne v. Flores, 521 U.S. 507, 536 (1997) (Stevens, J., concurring).

160. Id. at 537.

161. Id. at 536-37.

162. See Ariz. Rev. Stat. § 41-1493.01 (1999); Conn. Gen. Stat. Ann. § 52-571b (West 1998); $1998 \mathrm{Fla}$. Sess. Law Serv. ch. 98-412 (West); 775 Ill. Comp. Stat. Ann. 35/10 (West 1999); R.I. Gen. Laws § 42-80.1-3 (1998); 1999 S.C. Acts 38, to be codified at S.C. Code Ann. § 1-32-40 (Law. Co-op. 1999); Tex. Civ. Prac. \& Rem. Code $\$ 110.001$ (1999); see also Ala. Const. amend. No. 622 (approved by referendum Nov., 1998). For a list of states with pending RFRA legislation, see <http://www.c-rf.org/states.htm>.

163. US CoNST. amend. I.

164. See, e.g., Christopher L. Eisgruber \& Lawrence G. Sager, Why the Religious Freedom Restoration Act Is Unconstitutional, 69 N.Y.U. L. REv. 437 (1994); Marci A. Hamilton, City of Boerne v. Flores: A Landmark for Structural Analysis, 39 WM. \& MARY L. REV. 699, 721 (1998); Scott C. Idleman, The Religious Freedom Restoration Act: Pushing the Limits of Legislative Power, 73 TEX. L. REv. 247, 295 (1994); Ira C. Lupu, The Failure of RFRA, 20 U. ARK. LiTILE RocK L.J. 575, 599-601 (1998); Jed Rubenfeld, Antidisestablishmentarianism: Why RFRA Really Was Unconstitutional, 95 Mrch. L. REv. 2347 (1997).

165. See, e.g., Thomas C. Berg, The New Attacks on Religious Freedom Legislation and Why They Are Wrong, 21 Cardozo L. REv. 415 (1999); Erwin Chemerinsky, Do State Religious Freedom Restoration Acts Violate the Establishment Clause or Separation of Powers?, 32 U.C. DAVis L. REV. 645 (1999); Timothy L. Hall, Omnimbus Protections of Religious Liberty and the Establishment Clause, 21 Cardozo L. REv. 539 (1999).

166. Boerne, 512 U.S. at 537. 
laws, while comparably serious secular commitments ... receive no such legal solicitude."167

The foundational flaw in this common criticism is that the Establishment Clause is not an "Equal Treatment Clause."168 Sherbert $v$. Verner $^{169}$ made this clear. Walz v. Tax Commission ${ }^{170}$ and Wisconsin $v$. $Y$ oder $^{171}$ further crystalized the concept. And if there was any remaining doubt, Hobbie v. Unemployment Commission ${ }^{172}$ eradicated it. In Hobbie, the Court acknowledged that it "has long recogmized that the government may (and sometimes must) accommodate religious practices and that it may do so without violating the Establishment Clause." 173 The Court reiterated this principle, and applied it again, im Corporation of the Presiding Bishop of the Church of Jesus Christ of Latter Day Saints v. Amos, ${ }^{174}$ which upheld the constitutionality of a religious entity exemption to Title VII in the face of an Establishment Clause challenge. ${ }^{175}$

The idea that neutrality toward religion compels equal treatment of religion and irreligion simply finds no support in the Supreme Court's jurisprudence. If it did, one would have to question the vitality of the Free Exercise Clause, which, after all, "means that in some circumstances religious practices will be protected from government interference and burdening in a manner that secular ones are not."176 Even Smith recognized this basic truth. ${ }^{177}$ In sum, "the often repeated assertion that religious

167. Eisgruber \& Sager, supra note 164 , at $453-54$.

168. See Hall, supra note 165 , at 555 ("[T]he often-repeated assertion that religious believers and nonbelievers should be treated the same under the religion clauses fails to grasp the more complicated reality that has guided religion clause jurisprudence.").

169. 374 U.S 398,409 (1963) (holding that religious exemption to generally applicable benefits disqualification law did not offend the Establishment Clause because it simply reflected "neutrality in the face of religious differences").

170. 397 U.S. 664,673 (1970) (holding that exemptions from generally applicable property tax laws for religious organizations did not offend the Establishment Clause).

171. 406 U.S. 205 (1972) (holding that exemption of Amish children from compulsory attendance at high school was compelled by the Free Exercise Clause and did not offend the Establishment Clause).

172. 480 U.S. 136 (1987).

173. Id. at $144-45$ (holding that Florida's refusal to award unemployment compensation benefits to claimant, who was discharged when she refused to work on her Sabbath, violated free exercise clause of First Amendment, and that awarding benefits to Hobbie did not violate the Establishment Clause).

174. 483 U.S. 327,334 (1987).

175. But see Estate of Thornton v. Caldor, Inc., 472 U.S. 703, 710 (1985) (holding that state statute vesting Sabbath observers with an absolute and unqualified right not to work on their Sabbath violated the Establishment Clause). For a cogent explanation of why Thornton is the exception rather than the rule, see Chemerinsky, supra note 165, at 656-57.

176. Chemerinsky, supra note 165 , at 655 .

177. See Smith, 494 U.S. 872, 890 (1990) (holding that even where not constitutionally required, nondiscriminatory religious-practice exemptions may be " permitted ... or even ... desirable"). 
believers and nonbelievers should be treated the same under the religion clauses fails to grasp the more complicated reality that has guided religion clause jurisprudence."178 Fortunately for free exercise advocates, a majority of the current Court is not laboring under this misapprehension.

\section{III}

\section{Orchestrating a Piecemeal Approximation of RFRA Under Dole}

\section{A. Targeting Realistic Goals}

Critics have disparaged Dole as a back door to otherwise unattainable objectives. ${ }^{179}$ Fortunately for free exercise advocates, it is. It is important not to overestimate the door's size, however. A piecemeal spending strategy can replicate some, but not all, of RFRA's results. As previously noted, one of RFRA's virtues was its generality; the Act did not attempt to dictate specific results. Rather, RFRA sought to enhance religious freedom across the board by codifying a strict standard of review to be applied in all cases. ${ }^{180}$ This broad applicability made the Act both efficient and fair.

Seeking to emulate these results, Congress could again adopt omnibus-type legislation, this time exchanging the umbrella of the spending power for the rubric of the Fourteenth Amendment. As Professor Daniel Conkle points out, however, legislation stating that no state shall receive any federal funding unless that state forbids all state and local action that violates RFRA-like conditions would likely surpass even the broad limits of the spending power. ${ }^{181}$ Even in its emasculated state, the relatedness requirement would likely pose an obstacle. It would be a stretch indeed to convince the Court that the condition relates to program objectives when myriad objectives are mvolved. ${ }^{182}$ Such a strategy also risks resuscitating the coercion prohibition. If this imposing condition was not "so coercive as to pass the point at which "pressure turns into compulsion,"'183 seemingly nothing could be. ${ }^{184}$ Such an approach would be so aggressive as to invite invalidation. ${ }^{185}$

178. Hail, supra note 165 , at 555 .

179. See Richard A. EPSTEIN, BaRgaining with the State 157 (1993); Baker, supra note 22; William Van Alstyne, "Thirty Pieces of Silver" for the Rights of Your People: Irresistible Offers Reconsidered as a Matter of State Constitutional Law, 16 HARv. J.L. \& PuB. POL'Y 303 (1993); Squire, supra note 23.

180. See Laycock \& Thomas, supra note 60, at 215.

181. See Daniel O. Conkle, Congressional Alternatives in the Wake of City of Boerne v. Flores: The (Limited) Role of Congress in Protecting Religious Freedom from State and Local Infringement, 20 U. ARK. LITTLE ROCK L.J. 633, 673 (1998).

182. See id.

183. South Dakota v. Dole, 483 U.S. 203, 211 (1987) (quoting Steward Machine Co. v. Davis, 301 U.S. 548, 590 (1937)).

184. See Conkle, supra note 181, at 673 .

185. See id. 
RLPA suffers from these same infirmities. It is one thing to convince the Court that attaching a legal drinking age condition to highway funds furthers highway safety. It is quite another to convince the Court that ensuring that "the intended beneficiaries of federal program not be excluded because of their religious practice"186 is sufficiently related to the goals of all federal programs. ${ }^{187}$ And as Professor Chai Feldblum told Congress, eliminating the threat of canceling stubborn states' funds does not eliminate the coercion problem: "The coercion is not that federal funds might be withdrawn as a remedy ... it is that it may not be realistic for the State to reject the federal financial assistance in the first place." 188

Thus, Congress must content itself with a piecemeal spending-based strategy-a strategy that suffers by comparison. As the analysis below illustrates, the spending power is a blunt tool. Using it to enhance religious freedom has definite drawbacks. Congress must become outcoinecommitted in some instances, while in others it will be powerless to do anything. Spending also condemns Congress to being forever "behind the ball," as Congress can only remedy laws that burden free exercise after it discovers them, and then only insofar as these laws bear some relation to a federal funding program. Strategic spending is clearly not an ideal solution, but it is a solution nonetheless.

\section{B. The Powers of the Purse}

The section below provides a sampling of federal grant programs to which Congress could attach conditions im order to achieve discrete victories for religious freedom. As befits this ad hoc approach, the programs are presented in an ad hoc order.

\section{Unemployment Compensation Administration Grants}

Smith's rational basis standard lowers the bar states must clear im order to enforce "neutral" laws that "only incidentally" burden religion. In

186. Laycock Testimony, supra note 85 , at $* 2$.

187. In his testimony before the Senate Judiciary Committee, Professor Chai Feldblum concluded that

[e]ach of [Dole's] requirements becomes a bit more complicated to satisfy in the context of justifying RLPA's mandate that states and localities defend every neutral law that may burden rehigion as the least restrictive ineans of furthering a compelling government interest. This is not to say that RLPA would not necessarily meet each of these requirements. It is only to say that as the analysis becomes more complicated, opportunities may be created for the Supreme Court to narrow Congress' Spending Clause power. These possible conplications mean that Congress might well consider whether there are specific forms of religious liberty which are best justified under the Spending Clause power-and then use the spending power to protect those specific interests.

Legislation to Protect Religious Liberty: Hearings Before the Senate Comm. on the Judiciary, 106th Cong. (1999) (statement of Chai Feldblum, Professor, Georgetown Univ. Law Center), available in 1999 WL 20011244, at *8.

188. Id. at $* 9$. 
the context of unemployment compensation, Smith means that states can lawfully refuse to grant exemptions from benefits disqualifications even if the disqualifying misconduct is religiously inotivated and even if the state has no coinpelling reason for doing so. Overturning this aspect of Smith is within Congress's power. Following Dole's example, Congress could require states to recognize religious exceptions to generally applicable benefits disqualifications, or to at least employ a inore stringent standard of review as a condition of receiving soine portion of federal unemployment insurance assistance. For some, like Sherbert, the protection this condition affords might prove redundant. For others, like Smith and Black, however, it would bridge a crucial gap by encouraging states to grant exemptions from generally applicable criminal laws when there is no coinpelling reason not to do so.

All states receive federal grants from the Department of Labor to offset the cost of administering and operating their unemployment insurance scheines. These grants, made pursuant to 42 U.S.C. $\S \S 501-504,1101$ $1109,{ }^{189}$ are quite sizable. In 1999 , for example, they are expected to total $\$ 2.4$ billion dollars. ${ }^{190}$ Conditions on uneinployment compensation administration grants would not be novel. Indeed, Section 503 already mcludes a number of conditions that states inust satisfy in order to qualify for these funds. ${ }^{191}$ For example, states must provide for payment exclusively through public einployinent offices and produce any reports the Secretary of Labor may request in order to inaintain their grants. ${ }^{192}$ Similarly, Section 503(a)(3) requires states to afford a fair hearing to citizens whose claims the state denies. ${ }^{193}$

Section 503(a)(3)'s einphasis on the just administration of the system is sigmificant, particularly in view of the fact that sections 1101 through 1109 and sections 501 through 504 lack any discussion of the purposes of the acts. Section 503(a)(3) manifests Congress's interest in ensuring persons are not wrongfully denied benefits. Surely this interest includes preventing denials that are based on sincere religious practices as much as preventing denials premised on factual inaccuracies.

Dole's weak relatedness requirement suggests that Congress could constitutionally amend Section 503 to read:

189. See 42 U.S.C. $\$ \S 501-504,1101-1109$ (West 1998).

190. See Office of Management and Budget and General Servs. Admin., 1999 Catalog of Federal Domestic Assistance 482 (1999) [hereinafter 1999 Catalog]. This amount is not divided equally among the states. Rather, because federal funds reimburse the states for the costs of administering their respective programs plus one half of extended benefits, allocations are principally determined by states' respective numbers of unemployment compensation claimants. For this reason, grants vary widely. In 1998 , for example, grants ranged from as little as $\$ 1.5$ million to as much as $\$ 500$ million dollars. See id.

191. See 42 U.S.C. $\$ 503$ (West 1998).

192. See 42 U.S.C. $\$ 503(a)(2)$, (a)(6) (West 1998).

193. See 42 U.S.C. § 503(a)(3) (West 1998). 
The Secretary of Labor shall make no certification for payment to any State unless he or she finds that the law of such State, approved by the Secretary of Labor under the Federal Uneinployinent Tax Act, includes provision for ...11) waiver of generally applicable benefits disqualifications for applicants whose sincere religious belief compels the objectionable or criminal conduct in the absence of a compelling state interest.

Doing so would restore greater protection for free exercise in the uneinployinent benefits arena.

\section{Law Enforcement Funds}

Requiring states to recognize a religious exemption to generally applicable benefits disqualifications would win Smith and Black their unemployinent benefits. It would not, however, return to them their jobs or expunge their records of a potential drug use conviction. This is becanse sacramental peyote use constitutes a crime in inany states. If Congress wanted to reinedy this situation, however, it could do so by strategic spending as well.

Two federal law enforcement programs afford Congress the opportumity to induce states to exempt religious peyote use froin criminal prosecution. The first potential tool is the Bryne Formula Grant Program. As 42 U.S.C. $\$ 3751$ (a) explains, the purpose of this program is to support "national drug control priorities." help "enforc[e] State and local laws that establish offenses similar to offenses established in the Controlled Substances Act and to improve the functioning of the criminal justice system with emphasis on violent crime and serious offenders." ${ }^{195}$ In view of these purposes, it would not seem unrelated for Congress to require that states receiving them agree not to prosecute citizens for the religious use of peyote. States failing to comply could forfeit some of their Bryne Formula funds, which range between $\$ 500,000$ and $\$ 52$ million per year. ${ }^{196}$

Alternatively, Congress could attach a "no peyote prosecution" condition to the Local Law Enforceinent Block Grants Program. The program goal is to reduce crime and improve public safety. ${ }^{197}$ The Act specifies seven purposes for which the funds may be spent. The first of thesepaying officers' salaries ${ }^{198}$ — is undoubtedly very popular among the

194. 42 U.S.C. $\$$ 3751(a) (West 1995).

195. 42 U.S.C. $\S 3751$ (b) (West 1995) (internal citation omitted).

196. Congress allocated $\$ 47,000,000$ for the Bryne Formula Grant Program in 1999. See Omnibus Consolidated and Emergency Supplemental Appropriations Act, Pub. L. No. 105-277, 12 Stat. 2681, 2181-61 (1999). The bulk of these funds is allocated among states based on their relative shares of the U.S. population. See 1999 CATALOG, supra note 190, at 442.

197. 1999 Catalog, supra note 190, at 451.

198. See id. at 452 . 
recipients. Importantly, however, establishing or supporting drug courts is also a permitted use of funds. ${ }^{199}$

Given this focus on abating and prosecuting drug offenses, a condition requiring states not to prosecute religious use of peyote or other drugs absent a compelling state imterest would appear to be related. Just as underage drinking impeded Congress's aim of improving highway safety through highway construction, ${ }^{200}$ prosecution of religiously inspired peyote ingestion impedes Congress's aim of prosecuting drug offenders who pose dangers to society. After all, even Oregon tacitly admitted that religious peyote use posed little threat to the community. ${ }^{201}$

For the 1999 fiscal year, Congress appropriated approximately $\$ 523$ million to local law enforcement block grants. ${ }^{202}$ Of this amount, states received directly a small portion. ${ }^{203}$ The bulk of the funds are allocated to local government units ${ }^{204} \mathrm{~m}$ proportion to the number of violent crinies in the locality in the preceding three years. ${ }^{205}$ Thus, states with a relatively low incidence of murder, aggravated assault, rape and robbery would be affected less by a condition on these funds since they qualify for less initially. All states, however, would be soinewhat affected if they chose not to comply with the posited condition. ${ }^{206}$

\section{Highway Funds}

In Dole, Congress famously harnessed highway funds to obtain states' cooperation in establishing a uniform drinking age. If it so desired, Congress could use the same tool in the same way to enhance free exercise protection, particularly for a few vulnerable religious iminorities. For example, conditions on highway funds could be instrumental in protecting the Amish from the forced display of fluorescent triangles on their buggies in contravention of their faith. As Eli Hershberger explained to Minnesota's Supreme Court, the Old Order Amish faith mandates

199. See id. There is a federal spending program dedicated exclusively to supporting the establishment and functioning of drug courts. Pursuant to 42 U.S.C. $\$ \S 3796 \mathrm{ii}$ to ii-8 (West 1995), states and local governments can apply for project grants to develop and implement drug court programs to deal with non-violent drug offenders. I have not recommended attaching conditions to this program simply because it is unclear whether all states avail themselves of it.

200. See South Dakota v. Dole, 483 U.S. 203, 209 (1987).

201. Oregon itself changed its law shortly after Smith to exempt sacramental peyote use from criminal prosecution. See OR. REv. STAT. § 475.992(5) (1997).

202. See Omnibus Consolidated and Emergency Supplemental Appropriations Act, Pub. L. No. 105-277, 12 Stat. 2681, 2181-62 (1999).

203. See 1999 CATAlog, supra note 190 , at 453.

204. These are defined as towns, townships, villages, cities, counties, or recognized governing body of an Indian tribe or Alaskan native village that carry out substantial governmental duties or powers. See id. at 453.

205. See id. at 453 .

206. In 1998, every state and 3000 local law enforeement agencies received these funds. See 1999 Catalog, supra note 190 , at 452. 
separation from the inodern world. ${ }^{207}$ Minnesota's slow-moving vehicle (SMV) emblem, with its "loud" colors and triangular shape, constitutes a "worldly symbol" which Hershberger believes St. Paul's Epistles oblige him and his fellow believers to avoid. ${ }^{203}$

The Minnesota court initially sided with the Hershbergers. ${ }^{209}$ The state, it said, had not shown that its compelling interest in traffic safety could not be served by a less intrusive alternative. ${ }^{210}$ That is, the state failed the coinpelling interest test. ${ }^{211}$ In 1990, however, the Supreme Court vacated that decision and renianded the case for further consideration in light of Smith. ${ }^{212}$ On remand, the Minnesota Supreme Court decided that whether or not the Free Exercise Clause protects the Hershbergers, the Minnesota Constitution does. ${ }^{213}$

While the Minnesota Supreme Court declined to decide the case by assessing Hershberger's claim under Smith, it nonetheless made sone pertinent observations. Smith's holding, the court correctly noted, did away with the compelling interest test for laws burdening the free exercise exclusively. ${ }^{214}$ Thus, whether the compelling interest test applies depends on whether requiring the Amish to coinply with the slow-moving vehicle statute infringes on rights other than free exercise. ${ }^{215}$ The Minnesota court speculated that associational freedoms inay be implicated. ${ }^{216}$ The court thought there "might be nierit" in such claims. ${ }^{217}$ Whether other courts will concur is impossible to know. Under these circumstances, it would behoove Congress to proactively ensure that all states will respect the Amish's free exercise objections to fluorescent SMV signs.

Because Congress has set aside funds for the express purpose of improving highway safety, protecting the Amish from general highway laws that violate their religious beliefs is possible. The Highway Safety Act of 1966, codified at 23 U.S.C. $\$ \S 401-404$, establishes a formula grant

207. See Minnesota v. Hershberger, 444 N.W.2d 282, 284 (Minn. 1989).

208. See id. The Old Order Amish also object to fluoreseent colors in other contexts. At least one nember of the sect has been convicted for failing to wear hunter orange while hunting during deer hunting season even though his refusal to do so was religiously based. See State v. Bontrager, 683 N.E.2d 126, 131 (Ohio Ct. App. 1996) (finding that the state interest in having hunters wear orange during the 15-day hunting season was compelling).

209. See Hershberger, 444 N.W.2d at 282.

210. See id at 288 .

211. See id.

212. See Minnesota v. Hershberger, 495 U.S. 901 (1990).

213. See Minnesota v. Hershberger, 462 N.W.2d 396, 396-97 (Minn. 1990). In 1996, a group of Wisconsin OId Order Amish succeeded in convincing that state's Supreme Court that requiring thein to display the SMV emblem violated Wisconsm's state constitutional right to freedom of conscience. See Wisconsin v. Miller, 549 N.W.2d 235 (Wis. 1996).

214. See Hershberger, 462 N.W.2d at 396.

215. See id.

216. See id.

217. Id. 
program. The program aims to coordinate highway safety programs in order "to reduce traffic accidents, deaths, injuries, and property damage."218 The funds disbursed pursuant to this act nay be used to reinedy problems within nine priority areas. Significantly for the Amish, these areas include roadway safety. ${ }^{219}$

Amish religious beliefs could be accommodated without sacrificing road safety. Recognizing the need to alert drivers to their slow nnoving buggy, the Hershbergers requested to use silver reflective tape and lighted red lanterns in lieu of the offensive orange triangles. ${ }^{220}$ To ensure that Amish in other states are allowed this option, Congress could attach the following condition to the above-inentioned grants: "Receipt of five percent of these funds shall be withheld froin any state which does not evaluate religious objections to inandatory SMV signs using the coinpelling interest test." Alternatively, Congress could simply inandate that states allow the use of Hershberger's alternative: "Receipt of ten percent of these funds shall be withheld from any state which does not allow the use of silver reflective tape and red lanterns in lieu of the usual SMV sign."

Congress presently attaches similar conditions to federal highway funds. For example, Congress requires states to facilitate the travel and inoveinent of handicapped persons in order to qualify for these grants. ${ }^{221}$ One could argue that it is just a variation on a theme to require states to accommodate the travel and inovement of religious persons as well. Allowing the Amish to use silver tape would becoune just one more aspect of an approved highway safety program. ${ }^{222}$

Highway funds could also be leveraged to assist the Stephanie Kochers and Francis Quarings of the world. Kocher and her brother Patrick wanted to obtain "learner's" permits from the state of Pennsylvania. ${ }^{223}$ Both, however, were religiously opposed to obtaining the social security number required to do so. The two believed that the social security systein violated the Biblical edict that parents should provide for their children, not the other way around. ${ }^{224}$ Ruling in post-Boerne 1999, the Pennsylvania

218. 1999 CATALOG, supra note 190 , at 547 .

219. See id.

220. See Minnesota v. Hershberger, 444 N.W.2d 282, 289 (Minn. 1989).

221. See 23 U.S.C. § 402(b)(1)(D) (West 1995).

222. By law, states that fail to design and administer satisfactory highway safety programs risk a minimum of 50\% of their allocations, although these allocations can be recovered if the problem is remedied within the fiscal year. The allocations themselves are determined by two factors: total population (75\% of the total) and public road mileage (25\%). See 23 U.S.C. \& 402 (West 1995). Because of the manner in which funds are appropriated, the most populous states would stand to lose most from the imposition of such a coudition. The most populous states, however, may not be concerned about accommodating the Amish. Although the Amish live in nineteen states, $80 \%$ of the Old Order Amish are in Pennsylvania, Ohio and Indiana. See Origins of the Old Order Amish, (visited Mar. 11, 2000) <http://www.holycrosslivonia.org/amish/origin.htm>.

223. See Kocher v. Bickley, 722 A.2d 756, 757 (Pa. Cominw. Ct. 1999).

224. See id. at 757-58. 
court held that the two were simply out of luck because "the Pennsylvania statutory scheme to obtain a driver's license is neutral, generally applicable and serves legitimate government interests."225

If Francis Quaring had pursued her related claim in the sanie era she too would have been out of luck. Quaring was a woinan who understood the Bible's second commandment literally. She believed that the Commandment, which states "Thou shalt not make unto thee any graven image or likeness of anything that is im heaven above, or that is in the earth beneath, or that is in the water under the earth,"226 prohibited her from having her picture taken in order to get a Nebraska driver's license. ${ }^{27}$ Nebraska, however, refused to issue Ms. Quaring a license without a photograph. ${ }^{228}$

The Nebraska law requiring a photo driver's license was clearly a law of general applicability. It was not intended to target a particular faith, nor did it appear that its promulgators expected that it would have the slightest impact on free exercise. The law was solely intended to facilitate the sinooth administration of law enforcement by ensuring drivers' ready identifiability. Because her claim arose in 1984, however, before Smith and Boerne, the Eighth Circuit applied Sherbert's compelling interest test. ${ }^{229}$ Finding that Nebraska's state interest was not compelling, the appellate court enjomed state officials to issue Quaring a driver's license without a photo. ${ }^{230}$ An equally divided Supreme Court affirined the decision without comment. ${ }^{231}$

Smith and Quaring cannot coexist in the same universe. Either Sherbert's compelling interest test applies to laws of general applicability that burden free exercise, or it does not. Since Smith postdates Quaring by five years and was decided by a majority, the conclusion is inescapable that Quaring has been overruled.

However, Congress can protect people like Quaring ${ }^{232}$ and Kocher $^{233}$ if it so desires. The $\$ 21$ billion Federal-Aid Highway Program ${ }^{234}$ is the key to

\footnotetext{
225. Id. at 762 .

226. This is actually an extension of the second commandment, but it is the one to which Quaring subscribed.

227. See Quaring v. Peterson, 728 F.2d 1121, 1123 (8th Cir. 1984).

228. See id.

229. See id. at 1125-26.

230. See id.

231. Jensen v. Quaring, 472 U.S. 478 (1985) (per curium). Justice Powell took no part in deciding the case.

232. And there are inore people like her. Before Quaring got her day in court, three other jurisdictions had considered similar claims. See, e.g., Dennis v. Charnes, 571 F. Supp. 462 (D. Colo. 1983); Johnson v. Motor Vehicle Div., 593 P.2d 1363 (Colo. 1979); Bureau of Motor Vehicles v. Pentecostal House of Prayer, Inc., 380 N.E.2d 1225 (Ind. 1978). However anomalous the belief inay seem, it is nonetheless sincerely held. Mrs. Quaring, for example, took the prohibition of graven images so literally that she owned no photos, no television, and no decorative depictions of animals or plants.
} 
restoring protection of their free exercise rights. Congress has already attached to this program the drinking-age condition contested in Dole, as well as another condition relating to drivers' licenses: 23 U.S.C. $\$ 159$ conditions receipt of ten percent of federal highway funds upon states' temporary revocation of drug offenders' licenses. ${ }^{235}$

Interestingly, Congress did not include any findings or policy statement relating the condition of revoking drug offenders' licenses to the overall purpose of the Act in the section establishing this condition. Presumably then, no policy statement would be required to attach the following condition: "The Secretary shall withhold five percent of the amount required to be apportioned to any state under each of paragraphs (1),(3), and (5), or section 104(b) if the state has not enacted and is not enforcing a law that obliges the state to honor religious objections to photo drivers' licenses or social security numbers absent a showing of a compelling state interest."

\section{Historic Preservation Grants}

Boerne will undoubtedly be remembered for cabining Congress's Fourteenth Amendment enforcement power. Few people other than St. Peter's parishioners will likely recall the decision's immediate impact: St. Peter's Church was not permitted to expand. St. Peter's is a small, missionstyle church im Boerne, Texas. When the case came to trial, the parish had grown so much that forty to sixty of the parishioners could not be accommodated at some Sunday masses. ${ }^{236}$ To fix this problem, the San Antonio Archbishop applied to the City's Historic Landmarks Commission for permission to expand. Although St. Peter's Church was not itself a historic landmark, the Commission's permission was nonetheless necessary since a city ordinance required the Commission's approval of all changes to buildings within designated historic districts. ${ }^{237}$ City authorities denied the permit, prompting the ensumg litigation.

See Quaring, 728 F.2d at 1123 . She even went so far as to remove or obliterate images from the labels on the food she purchased. See id.

233. Certainly there are other people who object to the use of social security numbers on religious grounds. As Tennessee v. Loudon, 857 S.W.2d 878 (Tenn. Crim. App. 1993), illustrates, however, discerning whether objections to the numbers are religious or political could be complicated. In Loudon, the defendant used his social security number for some purposes, such as military service and employer withholding, but objected to the use of what he termed a "socialist surveillance number" for driver's license purposes, maintaining that he did "not have a SSN because that number is now becoming the mark of the beast against which we are warned in the Bible at Revelation 13: 16-18, 14: 11." Id. at 879-80.

234. This figure is for fiseal year 1999. See 1999 CATALOG, supra note 190, at 529.

235. States may escape the condition if the governor certifies that he is opposed to the enactment of such a law and both houses of the legislature in that state pass a resolution expressing opposition to such a law. See 23 U.S.C. § 159(a)(3)(B)(i)-(ii) (West 1995).

236. See City of Boerne v. Flores, 521 U.S. 507, 512 (1997).

237. See id. 
The Boerne ordinance burdens St. Peter's parishioners' free exercise of their religion. Forty to sixty of them literally cannot get in the door of the church. In the earlier era, this ordinance would have had to pass Sherbert's compelling interest test. Post-Boerne, however, that is not the case. Smith is again the law of the land, and Smith says only that these laws must pass the rational basis test. ${ }^{238}$ Consequently, the right to protect a building currently outranks the right to free exercise of religion.

St. Peter's is not the only church affected by this inversion of the hierarchy. Because churches constitute some of our oldest buildings, they are natural targets of landinarks preservation efforts. ${ }^{239}$ In 1996, for example, a Maryland church encountered problems with local landmarks preservation efforts when it applied to demolish an old monastery and chapel in order to better serve its parishioners. ${ }^{240}$ Two different churches in the Seattle area have also taken recourse to the courts to avoid application of historic preservation law to their churches. ${ }^{241}$ So too have the rectors of St. Bartholomew's church in New York, who object to the application of the city's landnarks preservation law to their church as a taking and an unconstitutional burden on the free exercise of their religion. ${ }^{242}$

Only some of these stories have happy endings for free exercise advocates; in the Maryland case, and one of the Seattle cases, the court specifically relied on state constitutional protections to find free exercise violations. ${ }^{243}$ Others, however, experienced no such luck. ${ }^{244}$ To ensure that preserving the free exercise in the churches will always take precedence over preserving the churches theinselves, Congress could simply attach a strategic condition to the Historic Preservation Fund Grants the Department of Interior supplies to states.

The National Historic Preservation Act, codified at 16 U.S.C. $\S 470$, seeks to foster the preservation of historic buildings and sites. Toward that end, it provides matching funds to states, which may use the funds to pay salaries, defray travel expenses, or finance actual preservation activities. ${ }^{245}$

238. Whatever one's opinion of historic preservation efforts, such efforts are surely rational.

239. Indeed, the centrality of preserving church property to the historic preservation mission recently prompted a group of Californians to challenge the constitutionality of an amendment to a statute that exempted the noncommercial property of religious organizations from landmark designations. The group claimed the amendment constituted an unconstitutional establishment of religion and an unconstitutional delegation of power. Notwithstanding these claims, the court upheld the constitutionality of the amendment exempting church property. See East Bay Asian Local Dev. Corp. v. Califormia, 81 Cal. Rptr. 2d 908, 918 (Ct. App. 1999).

240. See Keeler v. Mayor of Cumberiand, 940 F. Supp. 879 (D. Md. 1996).

241. See, e.g., First United Methodist Church of Seattle v. Hearing Examiner, 916 P.2d 374

(Wash. 1996); First Covenant Church v. City of Seattle, 840 P.2d 174 (Wash. 1992).

242. See Reetor of St. Bartholomew's Church v. City of New York, 914 F.2d 348 (2d Cir. 1990).

243. See Keeler, 940 F. Supp. at 887-88; First Covenant, 840 P.2d at 185.

244. See, e.g., St. Bartholomew's, 914 F.2d at 355-57 (holding that New York landmarks law did not violate free exercise or constitute a taking).

245. See 1999 Catalog, supra note 190, at 380. 
According to the Act's "[d]eclaration of policy," the federal government's aim is to "foster conditions under which our modern society and our prehistoric and historic resources can exist in productive harmony and fulfill the social, economic, and other requirements of present and future generations."246 Surely these "other requirements" include the religious requirements of today's faithful. Thus, it would be consistent with the Act's purpose to require states to have a compelling interest to deny a building permit sought by an active house of worship. If Congress so desired, it could go so far as to mandate exemptions from ordinances like Boerne's to the extent they affect churches in particular. Section 470 could simply be amended to say, "Any state that does not exempt churches, synagogues, or places of worship from historic preservation zoming ordinances shall have the amount available to it under this Act reduced by ten percent." 247

\section{Prison Funding}

Parishioners make far more sympathetic subjects than inmates. Perhaps this explains why, in O'Lone v. Estate of Shabazz, ${ }^{248}$ the Court diluted the test to be applied to inmates' free exercise claims. Although "convicted prisoners do not forfeit all constitutional protections," 249 their rights are not as rigorously protected as other citizens' rights: "[W]hen a prison regulation impinges on inmates' constitutional rights, the regulation is valid if it is reasonably related to legitimate penological interests. ${ }^{.250}$ This relaxed standard permitted New Jersey to deny Muslim inmates access to Jamu'ah, a weekly Islamic congregational service, without showing that the inmates could not be accounmodated by other reasonable means. ${ }^{251}$

By reinstating the compelling interest test across the board, RFRA essentially overturned $O$ 'Lone. ${ }^{252}$ Many members of Congress disfavored

246. 16 U.S.C. $\$ 470-1$ (1) (West 1995).

247. Other kinds of land use restrictions also compromise churches' abilitics to scrve their faithful. Regular zoning laws often significantly interfere with the same intercsts. For example, in Korean Bnddhist Dae Won Sa Temple v. Sullivan, 953 P.2d 1315 (Haw. 1998), the Supreme Court of Hawaii held that since RFRA was no longer operative, Honolulu could freely deny a variance to a Buddist Temple that unwittingly built its temple roof in excess of the height allowed in a residential neighborhood. The Buddhist temple, however, was not located within a historic district and thus would not be within the purview of a condition on historic preservation funds. Many other cases present similar conflicts between houses of worship and zoning ordinances. See, e.g., Cornerstone Bible Church v. City of Hastings, 948 F.2d 464 (8th Cir. 1991) (upholding a zoning ordinance which excluded churches from the area); Western Presbyterian Church v. Board of Zoning Adjustment, 862 F. Supp. 538 (D.D.C. 1994) (enjoining enforcement of zoning ordinance which prohibited church from feeding homeless on its premises); Grace Commnnity Church v. Town of Bcthel, 1992 WL 174923 (Conn. Super. Ct. 1992) (same); Area Plan Comm'n v. Wilson, 701 N.E.2d 856 (Ind. Ct. App. 1998) (upholding requirement that churches obtain special use permit before operating in a specific area).

248. 482 U.S. 344 (1987).

249. Id. at 348 (citing Bell v. Wolfish, 441 U.S. 520,545 (1979)).

250. Id. at 349 (citing Turner v. Safley, 482 U.S. 78,89 (1987)).

251. See id.

252. See, e.g., Werner y. McCotter, 49 F. 3d 1476 (1995). 
this result. Indeed, Senators Alan Simpson and Harry Reid sponsored an amendment to RFRA that would have excepted prisons from the Act entirely. ${ }^{253}$ The amendment failed, but the vote was close. ${ }^{254}$ Attorney General Janet Reno's input nnay have played a decisive role. Reno, who oversees the entire federal prison system, indicated her strong support for RFRA as drafted. "Prisons had operated under Sherbert for a number of years before $O$ 'Lone and Turner adopted a standard that is plainly less accommodating to the prisoners' exercise of religious rights. ... In iny view the four dissenters in $O^{\prime}$ Lone had the better of the arguinent.".255

Boerne breathed new life into $O^{\prime} L o n e$. Once again, this less accommodating standard apphies to immates' free exercise challenges. If Congress so desired, however, it could change this state of affairs. The Violent Crime Control and Law Enforcenent Act of $1994^{256}$ provides the avenue for doing so. Pursuant to this act, the Department of Justice will make grants of $\$ 2.6$ billion to states in fiscal year 1999.257 The states are to use the funds to build and expand prisons and jails to facilitate the incarceration of violent criminals. ${ }^{258}$ Large portions of these funds are already subject to important conditions. Section 13704 funds are contingent upon states' adoption and implementation of "truth in sentencing" laws, or laws that ensure that violent offenders serve at least eighty-five percent of their sentences. ${ }^{259}$ Section 13703 grants, moreover, require states to show an increase in violent crime convictions, or that the average period of incarceration for violent offenders has risen ${ }^{260}$ Both sections require recipients to implement pohicies recognizing the importance of crime victims' rights and needs. ${ }^{261}$

If recognizing victims' rights is reasonably related to the program's goal, then arguably recognizing prisoners' religious rights should be also. Under Dole's generous construction of the spending power, Congress could likely require that states accommodate immates' requests to attend religious ceremonies unless the prison's contrary interests are "compelling" and no less restrictive alternative is possible.

\section{Education Grants}

Although Smith abrogated the compelling interest test in most free exercise contexts, it preserved it in at least one. In Smith, Justice Scalia

\footnotetext{
253. See Laycock \& Thomas, supra note 60, at 243.

254. The amendment failed by a vote of 41-58. See id.

255. Id. at 241 (citation omitted) (omission in original).

256. 42 U.S.C. $\$ \S 13701-14223$ (West 1995).

257. See 42 U.S.C. \& 13708 (Vest 1995).

258. See 42 U.S.C. \& 13702(a) (West 1995).

259. See 42 U.S.C. $\$ 13704$ (West 1995).

260. See 42 U.S.C. \& 13703 (Vest 1995).

261. The act does not elaborate on what such a policy might mclude.
} 
intimated that strict scrutiny still applies to "hybrid situation[s]" in which a free exercise challenge is paired with a free speech or a parental rights claim. ${ }^{262}$ For examples of such "hybrid situations," Justice Scalia cited Wisconsin v. Yoder ${ }^{263}$ and Cantwell v. Connecticut, ${ }^{264}$ both cases in which the free exercise challenges triumphed. ${ }^{265}$ It is true that both cases presented considerations $\mathrm{m}$ addition to free exercise: Cantwell implicated free speech, while Yoder touched on parental rights. It is also true, however, that these aspects were peripheral aspects of the decisions, and not factors that influenced the Court's decision to apply the compelling interest test then. ${ }^{266}$ The hybrid claim idea is a Justice Scalia invention. Dissecting Justice Scalia's logic is beyond the scope of this Comment. It has led to serious confusion and, consequently, may not stand the test of time. ${ }^{267}$

While the Yoders successfully established parents' right to remove their children from public schools for religious reasons, ${ }^{268}$ parents exercising this right still face state-imposed obstacles. Home-schooling has proven especially problem-prone. Consider the divergent fates of the DeJonge and Vandiver families. The DeJonges taught their children at home utilizing a Christian curriculum. ${ }^{269}$ They refused to use certified teachers, as Michigan law required, because doing so violated their belief

\footnotetext{
262. Employment Div. v. Smith, 494 U.S. 872,882 (1990).

263. 406 U.S. 205 (1972).

264. 310 U.S. 296 (1940).

265. See Smith, 494 U.S. at 881.

266. In his decision, Justice Scalia characterizes both Wisconsin v. Yoder, 406 U.S. 205 (1972), and Pierce v. Society of Sisters, 268 U.S. 510 (1925), as cases dealing with parents' rights "to direct the education of their children." Smith, 494 U.S. at 881 . This is not an entircly accurate characterization of either case. The parental right at issue in Yoder was not a general right to educate children as one chooses. Rather, it was the right of the parent not to be forced to educate her children in a manner that contravened the parent's religious beliefs. Religion, not education, was the key element. Yoder itself makes this clear: "However read, the Court's holding in Pierce stands as a charter of the right of parents to direct the religious upbringing of their children." Yoder, 406 U.S. at 233.
}

267. The Ninth Circuit recently announced an extremely generous interpretation of "hybrid rights." See Thomas v. Anchorage Equal Rights Comm'n, 165 F.3d 692, 703 (9th Cir. 1999) (holding that a colorable takings and/or free speech claim compounded with a free exercise claim comprises a "hybrid right") withdrawn and reh'g en banc granted, 192 F.3d 1208 (9th Cir. 1999). By contrast, the Sixth Circuit has dealt with the "complete $[$ illogic $[$ " of the hybrid rights exception by throwing it out. In Kissinger v. Board of Trustees, 5 F.3d 177 (6th Cir. 1993), the court announced its plan to simply ignore the distinction entirely and proceed as if Smith applied categorically to all neutral, generally applicable laws incidentally burdening free exercise rights. See Kissinger, 5 F.3d at 180. But see Vandivcr v. Hardiu County Bd. of Educ., 925 F.2d 927 (6th Cir. 1991) (recognizing the hybrid rights distinction but rejecting it as inapplicable in the circumstances presented). Because there is no consensus on what constitutes a hybrid right and because courts like Kissinger plan to ignore them altogether, Congress can and should consider protecting free exercise rights related to education. Compare Swanson v. Guthrie Indep. Sch. Dist., 135 F.3d 694, 699 (10th Cir. 1998) (stating that "[i]t is difficult to delineate the exact contours of the hybrid-rights theory discussed in Smith"), with Thomas, 165 F.3d at 703 (describing the Supreme Court's hybrid rights explanation as "cryptic"), and Kissinger, 5 F.3d at 180 .

268. See Yoder, 406 U.S. at 209.

269. See People v. DeJonge, 501 N.W.2d 127, 129 (Mich. 1993). 
that scripture "specifically teaches that parents are ... responsible to God for the education of their children."270 Noting that both free exercise and parental rights were involved, the Michigan court applied strict scrutiny and struck down the teacher certification requirement. ${ }^{271}$

Although their claim ostensibly involved the same two rights, the Vandivers did not fare so well. For religious and other reasons, Ronald and Kathy Vandiver home-schooled their son Brian during his sophomore year. ${ }^{272}$ The Vandivers challenged on religious grounds the requirement that Brian pass equivalency exams upon his return to public school to earn credit for his Christian course of instruction the year before. ${ }^{273}$ The Sixth Circuit Court of Appeals concluded that no "hybrid right" was involved. ${ }^{274}$ Brian had reached the age of eighteen; thus, he had a free exercise claim and his parents had a parental rights claim but since he had recently attained the age of eighteen, the latter no longer mattered. The court held that under the Smith's rational basis standard, Brian's "free exercise challenge must fail.".275 There were two students, two similar claims, and two divergent outcomes attributable to the hybrid rights distinction.

It is within Congress's power to protect free exercise rights in public education settings, even when no hybrid rights are involved. Congress has tools at its disposal to ensure that states continue to grant religious exemptions to compulsory education laws and to ensure that states impinge on parents' choice of education curricula only under the most compelling circumstances. Among the most powerful of these tools is the Elementary and Secondary Education Act of $1965 .{ }^{276}$

Title I of that act makes grants available to states in order to improve education ${ }^{277}$ and help states meet performance standards. ${ }^{278}$ The program is large. In 1998, appropriations exceeded $\$ 7$ billion. ${ }^{279}$ In 1998, individual state awards ranged from $\$ 16$ million to $\$ 830$ million, ${ }^{280}$ with allocations

270. Id. at 130 n.4.

271. See id. at 134-41.

272. See Vandiver v. Hardin County Bd. of Educ., 925 F.2d 927, 929 (6th Cir. 1991).

273. Brian's parents initially agreed to the exams, but later changed their minds when they realized the workload completing two curricula would entail. See id. at 929 . Brian objected to the testing requirement on religious grounds, saying that he believed "the Lord will [not] allow me a bigger burden than I could carry." Id. at 931 (alteration m original).

274. See id. at $933-34$.

275. Id. at 933 .

276. 20 U.S.C. $\$ \S 6301-8962$ (West 1995). Title I funds are not the only vehicle that could be utilized in this way. The federal government also makes educational grants to states through its "Goals 2000" program in order to "support the development and implementation of comprehensive reform plans at the state, local, and school levels to improve the teaching and the learning of all children." 1999 CATALOG, supra note 190, at 896-97.

277. See 1999 CATALOG, supra note 190 , at 770 .

278. See 20 U.S.C. § 6301(b)(2), (d) (West 1995).

279. See 1999 CATALOG, supra note 190, at 771 .

280. See id. 
determined by relative concentrations of school age children from lowincome families. ${ }^{281}$

The aim of Title I funds is to improve education generally. Section 6301(d)(6) of Title 20 of the U.S. Code states that "affording parents meaningful opportunities to participate in the education of their children" is one way of furthering this purpose. ${ }^{282}$ A meaningful opportunity to participate in the education of their children is precisely what the Yoders, the DeJonges, the Vandivers, and families like them seek. Thus, a condition rendering a portion of Title I funds conditional upon states' recognition of a religious exenuption from compulsory education laws dovetails nicely with the act's purpose. Arguably, such a condition is not only relevant ${ }^{283}$ to the purpose of the federal program, it is essential. Thus the following condition would likely be permitted under the Spending Clause: "Title I funds allocated to a state will be reduced by ten percent if that state does not apply strict scrutiny to laws burdening parents' religiously motivated educational choices, regardless of whether the choice concerned constitutes a 'hybrid right."'

IV

The Post-Dole Prognosis: Weighing the Potential IMPACT OF SPENDING REFORM PROPOSALS

\section{A. The Heir Apparent}

The Supreme Court decided Dole in 1987. Since that time, five new justices have joined the Court, altering its composition dramatically. ${ }^{284}$ The continued vitality of Dole may depend on a headcount: If an analogous case arose again, could the surviving three members ${ }^{285}$ of the Dole n1ajority garner the two crucial votes from the crop of recent appointees? Of Justices Ginsburg, Souter, Breyer, Kennedy and Thomas, the former three are much likelier candidates than the latter two to support the holding in Dole. It is safe to assume, however, that the Court's personnel changes added at least one vote to the anti-Dole cainp. ${ }^{286}$ While it would be an exaggeration to claim that the decision is doomed, it is fair to say that it appears imperiled. Justice O'Connor's distaste for the decision coupled with personnel

281. See id.

282. 20 U.S.C. $\$ 6301$ (d)(6) (West 1995).

283. Dole cites with approval Ivanhoe Irrigation Dist. v. McCracken, 357 U.S. 275 (1958), which states, "the Federal Government may establish and impose reasonable conditions relevant to federal interest in the project and the over-all objectives thereof." South Dakota v. Dole, 483 U.S. 203, 208 (1987).

284. These are Justices Kennedy, Souter, Thomas, Gimsburg, and Breyer.

285. These are Justices Rehnquist, Stevens, and Scalia.

286. That vote probably belongs to Justice Thomas. For a persuasive argument that his concurring opinion in Lopez suggests a willingness to overrule Dole, see Baker, supra note 22, at 1914 n.12. 
changes and the Court's recent neo-federalist agenda should give prudent legislators pause. The question becomes, if Dole is overruled, what will take its place, and can a strategic spending strategy survive it?

Justice O'Connor's interpretation of the spending power is the only heir apparent. Justice O'Connor parts company with the Dole majority on two inajor points. First, she believes that to be constitutional, conditions need to be substantially, not just minimally, related to the funding objective ${ }^{287}$ She derives this belief from her understanding of the origin of constitutional conditions, which she, unlike Chief Justice Rehnquist, attributes directly to the spending power. Because she perceives the legitimacy of conditions as deriving from the spending power itself, Justice O'Connor concludes that truly related conditions help Congress effectuate permissible spending objectives, and no more. ${ }^{288}$ Consequently, conditions must "specif[y] in some way how the money should be spent."289 A condition that goes beyond this task is "not a condition, but a regulation, which is valid only if it falls within one of Congress' delegated regulatory powers." ${ }^{290}$

In Dole, Justice O'Connor derided the majority's relatedness analysis as "cursory and unconvincing." 291 It was, and that was the point. The Dole Court could have put teeth in the relatedness requirement, but it expressly declined to do so. ${ }^{292}$ Justice O'Connor's stated desire is to reverse that trend. For the reasons described below, however, even adoption of her spending power proposal would not foil a spending-based strategy aimed at enhancing free exercise protection.

\section{B. Justice O'Connor's Porous Proposal}

According to Justice $O^{\prime}$ Connor, the spending power only empowers Congress to spend for the general welfare. If Congress wants to regulate, it must do so pursuant to soine other enuinerated power. Thus, the constitutionality of a condition turns on the condition's objective. "The

\footnotetext{
287. See Dole, 483 U.S. at 214-16 (O'Connor, J., dissenting).

288. See id. at 216.

289. Id. (citation omitted).

290. Id. (citation omitted). Justice O'Connor attributes her approach to United States v. Butler, 297 U.S. 1 (1936), one of the Court's first Spending Clause decisions. In Butler, the Court emphasized the "obvious difference between a statute stating the conditions upon which moneys shall be expended and one effective only upon assumption of a contractual obligation to submit to a regulation which otherwise could not be enforced." Butler, 297 U.S. at 73. The blurring of this distinction, the Court held, would "tend to nullify all constitutional limitations upon legislative power." Id. at 74. It is this nullification that concerns Justice $O$ ' Connor: "If the spending power is to be limited only by Congress' notion of the general welfare, the reality ... is that the Spending Clause gives 'power to the Congress to tear down the barriers, to invade the states' jurisdiction, and to become a parliament of the whole people, subject to no restrictions save such as are self-imposed." Dole, 483 U.S. at 217 (O'Connor, J., dissenting) (quoting Butler, 297 U.S. at 78).
}

291. Dole, 483 U.S. at 213 (O'Connor, J., dissenting).

292. See id. at 209 n.3. 
appropriate inquiry, then, is whether the spending requirement or prohibition is a condition on a grant or whether it is a regulation."293

The challenge for Justice O'Connor is to devise a system to distinguish between the two. Justice O'Connor adopts the approach suggested by the National Conference of State Legislatures:

The difference turns on whether the requirement specifies in some way how the money should be spent, so that Congress' intent in making the grant will be effectuated. Congress has no power under the Spending Clause to impose requirements on a grant that go beyond specifying how the money should be spent. ${ }^{294}$

In the abstract, Justice O'Connor's reformulation of the Spending Clause offers a clear dividing line between spending and regulation. It is less clear, however, that it would do the same in practice. Rather than ending the practice of regulating by conditioning, Justice O'Connor's spending power reform would just make the practice more discrete.

The Dole case itself provides an apt illustration. Justice O'Connor objected to Congress's imposition of the drinking age condition, saying, " $[\mathrm{r}]$ ather than a condition determining how federal money shall be expended, it is a regulation determining who shall be able to drink liquor." ${ }^{295}$ Indeed, if the funds are intended simply to build roads, the drinking age criterion blatantly offends Justice O'Connor's rule that the condition "specif[y] in some way how the money should be spent."296 What if, however, the legislators were more creative? What if Congress dictated that the funds be expended in order to build "safe roads" or even "safe roads where a twenty-one-year-old drinking age obtains"? Would that not be specifying in some way how the money should be spent? Could Congress not transform this "regulation" into a constitutional "condition" under Justice O'Connor's system simply by folding the regulation into the purpose of the funds rather than simply tacking it on at the end?

Justice O'Connor's proposed reform invites such semantic manipulation. Free exercise advocates, for example, could simply couch their "regulations" in the purposes of the act. Rather than saying to states "if you want unemployment insurance compensation, you must grant religious exemptions to benefits disqualifications," Congress could say "we are allocating $\$ \mathrm{X}$ to reimburse religiously sensitive state unemployment compensation schemes." The same result would obtain: States that exempt Sabbatarians from Saturday work rules and Native Americans from Smith-style disqualifications would get funds, while others would not. Rather than saying "if you accept this law enforcement block grant, you

293. Dole, 483 U.S. at 216 (O'Connor, J., dissenting) (citation omitted).

294. Id. (citation omitted).

295. Id. at 218.

296. Id. at 216 (citation omitted). 
cannot criminalize religious peyote use," Congress might have to substitute "The purpose of these funds is to enhance the ability of free-exercise sensitive states to enforce the laws and pursue drug prosecutions."

Although Justice O'Connor clearly wants to demand a tighter connection between conditions and the purposes of the federal program, the test she advances will not fulfill her goal. The requirement that conditions "specif[y] in some way how the money should be spent" is exceedingly porous. While not all conditions that would survive Dole would survive Justice O'Connor's test, a great many of them could with a modicum of semantic tweaking. ${ }^{297}$ Thus, free exercise advocates could still use the conditional spending to their advantage, even if the Court follows Justice O'Connor in interpreting the Spending Clause.

\section{CONCLUSION}

In Boerne, the Court won a battle, but it may not have won the war. Congress has not exhausted all avenues of enhancing free exercise protection. Dole pronounced a very generous construction of the spending power, upon which Congress could capitalize to pursue piecemeal the free exercise protections it sought to establish through RFRA.

By attaching carefully crafted strings to federal funds, Congress can reverse some of the damage that Smith did to free exercise protection. For example, Congress can effectively mandate that states recognize religious exemptions to generally applicable unemployment benefits disqualifications. It can ensure that states continue to exempt children from compulsory education on religious grounds and that they minimize obstacles to religiously inspired home-schooling. It is also within Congress's power to ensure that driver's license bureaus and traffic authorities are similarly accommodatimg of sincerely held religious beliefs, and that historic buildings are not preserved at the expense of those who would worship in them. Piece by piece, little by little, Congress can achieve through spending part

297. In Conditional Federal Spending After Lopez, Professor Lynn Baker makes a valiant and partially successful attempt to close the holes in Justice O'Connor's proposal. Noting the weakness of Justice O'Connor's "regulatory" spending distinction, Baker suggests an alternative way of winnowing out offensive conditions. "[C]ourts [should] presume invalid those conditional offers of federal funds to the states which, if accepted, regulate them in ways that Congress could not directly mandate. This presumption can subsequently be rebutted, however, if Congress shows that the offer of funds is 'reimbursement' spending rather than 'regulatory' spending legislation." Baker, supra note 22, at 1953. At first glance, Baker seems to be repeating Justice O'Connor's error. Baker also makes a determination of the "regulatory" nature of a condition central to her inquiry. Unlike Justice O'Connor, however, Baker provides an analytical framework that clearly divides "regulatory conditions" from the rest. Regulatory conditions are those which (1) regulate the states in ways in which Congress could not directly mandate and (2) which provide funds im excess of those necessary to reimburse the states for its expenditures related for the specified purpose. See id. If the Court were to adopt Baker's embellishments, the future for the strategy proposed herem would be much less bright. 
of what it sought to accomplish through RFRA. This strategy is a suboptimal strategy, but it could, nonetheless, be an effective one. 